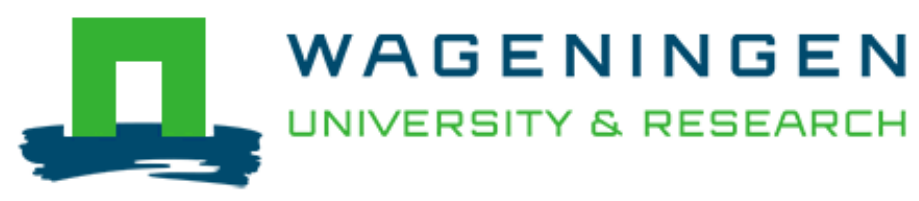

Comparison of bovine milk fat and vegetable fat for infant formula: Implications for infant health

Hageman, J. H. J., Danielsen, M., Nieuwenhuizen, A. G., Feitsma, A. L., \& Dalsgaard, T. K.

This is a "Post-Print" accepted manuscript, which has been published in "International Dairy Journal"

This version is distributed under a non-commercial no derivatives Creative Commons (c) (1) () $(9$ reproduction in any medium, provided the original work is properly cited and not used for commercial purposes. Further, the restriction applies that if you remix, transform, or build upon the material, you may not distribute the modified material.

Please cite this publication as follows:

Hageman, J. H. J., Danielsen, M., Nieuwenhuizen, A. G., Feitsma, A. L., \& Dalsgaard, T. K. (2019). Comparison of bovine milk fat and vegetable fat for infant formula: Implications for infant health. International Dairy Journal, 92, 37-49. DOI: 10.1016/j.idairyj.2019.01.005

You can download the published version at:

https://doi.org/10.1016/j.idairyj.2019.01.005 


\section{Comparison of bovine milk fat and vegetable fat for infant formula: implications}

\section{2 for infant health}

3

4 Jeske HJ Hageman ${ }^{\text {a.b* }}{ }^{*}$ Marianne Danielsen ${ }^{\text {c^^}}$, Arie G Nieuwenhuizen ${ }^{\mathrm{a}}$, Anouk L Feitsma ${ }^{\mathrm{b}}$,

5 Trine K Dalsgaard ${ }^{\mathrm{c}}$

6

$7 \quad{ }^{a}$ Human and Animal Physiology, Wageningen University, de Elst 1, 6708 WD Wageningen,

8 the Netherlands, jeske.hageman@wur.nl, arie.nieuwenhuizen@wur.nl

$9{ }^{\mathrm{b}}$ FrieslandCampina, Stationsplein 1, 3818 LE Amersfoort, the Netherlands,

10 anouk.feitsma@frieslandcampina.com

$11{ }^{\mathrm{c}}$ Department of Food Science, Aarhus University, Blichers Allé 20, DK-8830 Tjele Aarhus,

12 Denmark, marianne.danielsen@food.au.dk, trine.dalsgaard@food.au.dk

13 *equal contribution

14

^Corresponding author: marianne.danielsen@food.au.dk, Aarhus University, Blichers Allé

20, Postboks 50, DK-8830 Tjele, Denmark

17

18 Declarations of interest: JH and AF are employees of FrieslandCampina

19

20 ORCID for authors:

21 Trine Kastrup Dalsgaard: orcid.org/0000-0002-5635-4102

22 Marianne Danielsen: https://orcid.org/0000-0002-8850-5649

23 Anouk Feitsma: https://orcid.org/0000-0003-3946-8869

24 Jeske Hageman: https://orcid.org/0000-0002-4101-2505

25 


\section{Abstract}

27 Fat is an important component of human milk and infant formula (IF), delivering half of the 28 energy a baby needs. Nowadays, mostly vegetable fats are used in IFs, however, the use of 29 bovine milk fat in formulas is currently increasing. Bovine milk fat contains a different composition of fatty acids and lipid components than vegetable fats. We have compared the lipid profile of human and bovine milk to infant formulas with different fat sources.

32 Furthermore, current knowledge of how infant digestion, absorption, metabolic responses, gut

33 immunity, microbiota and/or cognition is affected by dietary fat is reviewed. The possible

34 opportunities and drawbacks of the application of bovine milk fat in infant nutrition are

35 described. Future perspectives for the development of IF containing bovine milk fat and future 36 research directions are highlighted.

\section{Introduction}

39 Milk is essential for babies. For a newborn child breast milk is the preferred nutrition (EU 40 Directive 2006/141). However, when breastfeeding is not an option, infant formula (IF) is the 41 best alternative. About four percent of human milk consists of fat, which delivers approximately $50 \%$ of the total energy to infants (Manson \& Weaver, 1997). Therefore, this is a major component to focus on in the development of optimal IF.

44 Currently, different fat sources are used for IF, of which most contain a mixture of vegetable fats.

45 The most commonly used vegetable fats are coconut oil, corn oil, soybean oil, palm oil (palm 46 olein, palm kernel oil), (high oleic) sunflower oil, high oleic safflower oil and low erucic acid 47 rapeseed oil (Berger, Fleith, \& Crozier, 2000; Mendonça, Araújo, Borgo, \& Alencar, 2017). 48 Besides vegetable fats, the addition of bovine milk fat to IF is quite common. Sun et al analyzed 180 infant formulas reflecting $75 \%$ of the market share in China, from which 66 products $(37 \%)$ contained bovine milk fat. Bovine milk fat is added to IF in two different ways; either as anhydrous milk fat (containing triglycerides and other components like cholesterol and fat-soluble 
52 vitamins), or as full fat milk or cream (containing besides triglycerides and cholesterol all 53 components of the fat globule membrane).

54 Until the 1970s, bovine milk fat was part of IF (Delplanque, Gibson, Koletzko, Lapillonne, \& 55 Strandvik, 2015; Innis, 2011), mainly through the use of whole milk in the recipes. However, as the formulas were further developed, animal fat was replaced by vegetable fats (Institute of Medicine, 2004). This was done for several reasons; to provide (higher levels of) mono- and polyunsaturated fatty acids (Innis, 2011), and due to the fear of contaminants, like dioxins. Also, it was believed that formulas similar to home-made evaporated milk formulas increased the level of constipation (Fomon, 2001a), and the odor of regurgitated butterfat was found to be unpleasant (Fomon, 2001b). In addition, the cost of using bovine milk fat was high, compared to the alternatives found in vegetable fats. Today, research focus is on adding complex lipids and milk fat globular membrane components to support infants' development (Koletzko, 2016). Furthermore, EFSA states that "the obvious and previously used staple sources of fat for use in the production of IF and follow-on formula are cow's milk, to a certain extent goat's milk and different types of vegetable oils" (EFSA Panel on Dietetic Products Nutrition and Allergies (NDA), 2014). In this review, we compare the composition of human milk fat, bovine milk fat and vegetable fats and focus on their implications for infant health.

\section{Lipid composition in bovine milk, human milk and infant formula}

Human as well as bovine milk contains approximately $4 \%$ fat in the form of globules (Jensen,

71 Ferris, Lammi-Keefe, \& Henderson, 1990b; Månsson, 2008). During different stages of lactation

72 the total fat content and fatty acid composition changes to a minor extent (Giuffrida et al., 2016;

73 Kay et al., 2005; Moltó-Puigmartí, Castellote, Carbonell-Estrany, \& López-Sabater, 2011; Qi et 74 al., 2018; Stoop, Bovenhuis, Heck, \& van Arendonk, 2009). However, since this is not the focus of this review, and since the recommendations for the composition of IF is the same for newborns and up to 6 months, we chose to only include mature human milk as comparison for IF in this review. Fat globules are filled with triglycerides, which represent $98 \%$ of the total fat (Jensen,

78 Ferris, Lammi-Keefe, \& Henderson, 1990a). The so-called milk fat globular membrane (MFGM), 
which is composed of proteins and lipids, cover the milk fat globules (MFG). Proteins within the MFGM include glycoproteins and enzymes (Dewettinck et al., 2008; Zou et al., 2015). The structure of the MFGM was recently reviewed by Martini et al. (Martini, Salari, \& Altomonte, 2016) and nicely illustrated by Hernell et al (Hernell, Timby, Domellöf, \& Lönnerdal, 2016). The lipids within the MFGM include mainly polar lipids, but also some neutral lipids like triglycerides, diglycerides, monoglycerides, sterols (mainly cholesterol) and gangliosides. Furthermore, bovine milk fat contains trace amounts of ether lipids, hydrocarbons, fat-soluble vitamins, flavor compounds and other minor compounds (Månsson, 2008). The triglyceride composition and structure, polar lipids and cholesterol are described in more detail below.

\subsection{Triglycerides}

The fatty acids in human and bovine milk fat, as well as in vegetable fat, are mostly present in the form of triglycerides ( $98 \%)$. A triglyceride consists of a glycerol backbone with three fatty acids attached to it. Both the fatty acids and the triglyceride structure of different fat sources are described in the sections below.

94

\subsubsection{Fatty acids}

Nearly 200 different fatty acids, ranging from C4:0-C26:0, are present in human milk fat (Jensen, Ferris, Lammi-Keefe, \& Henderson, 1990c; Månsson, 2008). For bovine milk fat this number is even higher, almost 400 fatty acids are present in bovine milk fat (Jensen et al., 1990a). Only about $15 \%$ of those are present at $1 \%$ or higher, the others are only present in trace amounts. Since most vegetable fats (except coconut oil) do not contain fatty acids ranging from C4:0-C12:0, and no odd-chain fatty acids (Dorni, Sharma, Saikia, \& Longvah, 2018) the variety of fatty acids in vegetable fats is lower compared to bovine and human milk fat Table 1 shows the fatty acid composition of human milk, bovine milk and IF products with different fat blends. For clarity, very low abundant fatty acids were left out. 
107 Table 1 contains an average fatty acid composition of mature human milk (studies from 2000 108 until 2018 were included). Of all fatty acids in human milk, almost $98 \%$ are long-chain fatty acids 109 (LCFA $(>\mathrm{C} 10)$ ), of which about $40 \%$ are saturated fatty acids (SFA). The remaining $2 \%$ of the 110 fatty acids in human milk fat consist of medium-chain fatty acids (MCFA (C6:0-C10:0)). Most 111 studies are not able to detect the short-chain fatty acid (SCFA) butyrate (C4:0) in human milk; 112 however, some studies do report the presence of butyric acid in low concentrations. For example, 113 Wan et al. showed that human milk of Chinese mothers contained $0.6 \mathrm{~g}$ butyric acid per $100 \mathrm{~g}$ 114 fatty acids (Wan, Wang, Xu, Geng, \& Zhang, 2010). The values represented in Table 1 are an 115 estimation of the true levels in human milk. Analytical factors influence the fatty acid 116 compositions, including differences in extraction protocols and detection methods. Furthermore, 117 there is a natural variation both between individual mothers and between geographical regions 118 (Kumar et al., 2016), since the fatty acid composition of human milk is influenced by diet as well 119 as genetics. To give an insight in these regional differences, data from human milk obtained in 120 Asia and Europa is presented. Some regional differences are observed, as the level of PUFA is 121 somewhat higher in Asia compared to Europe, and the level of SFA and MUFA is somewhat 122 lower. Overall, the fatty acid composition between regions is quite similar.

125 About $70 \%$ of bovine milk fat consists of SFA. Of all fatty acids, almost $90 \%$ are LCFA, $6-7 \%$ 126 are MCFA, and butyrate is present in about 3-4\%. The most characteristic fatty acids for bovine 127 milk fat are odd chain fatty acids, conjugated linoleic acid and butyrate. This latter fatty acid is 128 not present in vegetable fats and only present in trace amounts in human milk.

129 Bovine milk fat contains higher levels of saturated fatty acids compared to human milk fat, about 130 $67 \%$ vs $43 \%$ respectively, and lower levels of MUFA's (24\% vs $36 \%$ ) and PUFAs (2\% vs $18 \%$ ).

131 Even though low in human milk, docosahexaenoic acid (DHA) and arachidonic acid (ARA) are 132 present in even lower amounts in bovine milk fat. Similar to human milk fat, the main fatty acids 
133 present in bovine milk fat are oleic acid and palmitic acid (C16:0). In human breast milk, palmitic

134 acid alone accounts for approximately $10 \%$ of the infant's energy intake, making palmitic acid a

135 key nutrient for infants (Innis, 2015). In bovine milk fat, palmitic acid is present in higher levels 136 compared to human milk fat ( $30 \%$ vs $22 \%$ ), for oleic acid this is reverse ( $22 \%$ vs $34 \%)$. A major 137 difference between human milk fat and bovine milk fat is the level of linoleic acid. Human milk 138 fat contains around $15 \%$ linoleic acid, while in bovine milk fat this is only about $1.5 \%$.

\subsubsection{Fatty acids in vegetable fat}

141 Different vegetable fats present in IF are blended in such a way that the fatty acid composition

142 closely resembles that of human milk (Table 1). However, since different vegetable fats are used,

143 there is also some variation between products. This is indicated by the ranges in Table 1, which 144 shows examples of fat mixtures used in IF. Compared to an infant formula containing bovine milk 145 fat, an infant formula that contains only vegetable fat contains lower levels of butyrate and MCFA 146 and higher levels of MUFA. When a mixture of only vegetable fats is used, a source of palm oil 147 needs to be added to reach a similar level of palmitic acid as found in human milk. A vegetable 148 source of palmitic acid is palm (kernel) oil. IFs without palm oil contain only $8 \%$ of palmitic acid, 149 and higher levels of oleic acid, linoleic acid and lauric acid compared to human milk fat.

150

151

\subsubsection{TAG structure}

152 A triglyceride consists of a glycerol backbone with three positions for fatty acids to attach, the 153 outer positions are called sn-1 and sn-3, and the center position is called sn-2. Specific fatty acids 154 have their own favorable position at the glycerol backbone, which differ among species. With the 155 current analytical methods available, only the percentage of fatty acids at the sn-2 position of the 
total fatty acids can be determined. The fatty acids present at sn- 1 and sn- 3 cannot be determined

157 separately.

158

159

2.1.2.1 TAG structure in human milk fat

160 In human milk, the main fatty acid, palmitic acid, is mostly placed at the sn-2 position, representing about $70-88 \%$ of the total palmitic acid, see Table 2 (Bracco, 1994; López-López, López-Sabater, Campoy-Folgoso, Rivero-Urgell, \& Castellote-Bargalló, 2002; Sun, Wei, Su,

163 Zou, \& Wang, 2018). Of the other long-chain saturated fatty acids (LCSFA), 34-66\% are also

164 placed at the sn-2 position in human milk (López-López et al., 2002; Sun et al., 2018). The only

165 exception is stearic acid (C18:0), of which only 10\% is placed at the sn-2 position (López-López

166 et al., 2002; Sun et al., 2018). The major TAG structures present in human milk are structures

167 with palmitic acid at the sn-2 position, and oleic acid (18:1) attached to sn-1 or sn-3, like C18:1-

168 C16:0-C18:2, C18:1-C16:0-C18:1, and C16:0-C16:0-C18:1 (Linderborg et al., 2014; Morera

169 Pons, Castellote Bargalló, \& López Sabater, 1998; Tu, Ma, Bai, \& Du, 2017).

170

171

2.1.2.2 TAG structure in bovine milk fat

172 In bovine milk fat, butyrate is mostly located at sn-3. MCFAs, as well as C12:0-C16:0, are

173 preferably located at the sn-1 and sn-2 positions. Stearic acid (18:0) is selectively located at 174 position sn-1, while oleic acid is mostly present at sn-1 or sn-3 (Månsson, 2008). For bovine milk

175 fat, the amount of palmitic acid at the sn-2 position is about $40-45 \%$ of the total amount of palmitic

176 acid (Bracco, 1994). Sun et al. showed data for IFs containing bovine milk fat; however, the

177 percentages of bovine milk fat used were not specified. Here, the percentage of LCSFA

178 (excluding stearic acid) positioned at the sn-2, instead of sn-1 or sn-3, was between $30-49 \%$ (Sun

179 et al., 2018). Like human milk fat, bovine milk fat contains a wide variety of fatty acids, resulting in many different triglyceride structures. Just like human milk, the major TAG structures in 
181 bovine milk fat contain palmitic acid in the sn-2 position, and oleic acid attached to the sn- 1 or 182 sn-3 position (Jensen, 2002; Michalski, 2009).

183

The TAG structure of vegetable fats used in IF differ from human milk fat. For vegetable fat blends used in IF the amount of palmitic acid at the sn-2 position reaches levels of $10-20 \%$ (Bracco, 1994; Sun et al., 2018). Sun et al. reported that 19-59\% of the LCSFA are positioned at the sn-2 position in IFs with vegetable fats, of which some contain interesterified palm oil (Sun et al., 2018). Clearly, in vegetable fat-based IF's, high levels of triglyceride structures with saturated fatty acids at the sn-1 and/or sn-3 position are present, such as C18:1-C18:1-C16:0, C16:0-C18:1-C16:0, C18:2-C18:1-C16:0, and C16:0-C18:2-C16:0 (Tu et al., 2017). Since less different fatty acids are present in vegetable fat, also the pool of triglycerides is less diverse compared to human and bovine milk fat.

\subsubsection{Structured TAGs}

196 The distribution of fatty acids along the glycerol backbone at the sn- 2 vs sn- $1 / \mathrm{sn}-3$ positions can be changed with inter-esterification (Berger et al., 2000). Recently, TAGs generated through an enzymatic process from vegetable fats or combinations of vegetable and other fats e.g. from fish have become available (Álvarez \& Akoh, 2016; Ghosh, Sengupta, Bhattacharyya, \& Ghosh, 200 2016). The most common product is beta-palmitate, which is used in IF products currently on the 201 market. Beta-palmitate is the resulting product of the enzymatic inter-esterification of palm oil 202 and high oleic sunflower oil, where C16:0-C18:1n-9-C16:0 is transformed to C18:1n-9-C16:0203 C18:1n-9 (L. Zou, Pande, \& Akoh, 2016). These "structured TAGs" make it possible to produce 204 IFs with TAG structures higher in sn-2 palmitate, often above $40 \%$ (ranging from $39-47 \%$ ) of the total palmitic acid content (17-25\%) (Bar-Yoseph, Lifshitz, \& Cohen, 2013; Sun et al., 2018) . 
209 Polar lipids encompasses amongst others phospholipids and sphingolipids. Those lipids contain 210 a hydrophobic tail and a hydrophilic head (Dewettinck et al., 2008). Polar lipids have a 211 fundamental role in milk; the emulsification of fat in water (Contarini \& Povolo, 2013). The concentration of total polar lipids is comparable between human milk fat and bovine milk fat.

213 Human milk fat contains about $20.4 \pm 2.8 \mathrm{mg}$ of polar lipids per $100 \mathrm{ml}$ compared to $19.2 \pm 0.8$ $214 \mathrm{mg}$ of polar lipids per $100 \mathrm{ml}$ for bovine milk fat (calculated from Zou et al., 2013). The 215 composition of the different polar lipids is slightly different between the two different fat sources. 216 Furthermore, the exact phospholipid content of the bovine globule membrane is dependent on the 217 cow breed, season, feed of the cow and size of the globule (Z. Liu, Logan, Cocks, \& Rochfort, 218 2017; Michalski, 2009). The main polar lipids present, in both the human and bovine fat globule membrane, are phosphatidylcholine (PC), phosphatidylethanolamine (PE), phosphatidylinositol 220 (PI), phosphatidylserine (PS), and sphingomyelin (SM) (Dewettinck et al., 2008; X. Zou et al., 221 2015). Human milk contains higher levels of sphingomyelin $(40.2 \% \pm 1.1$ vs $27.4 \pm 1.1)$ and 222 phosphatidylserine $(14.4 \pm 2.0$ vs $7.3 \pm 1.0)$, while in bovine milk fat more 223 phosphatidylethanolamine is present $(12.5 \pm 2.9$ vs $30.2 \pm 2.7)$ (Zou et al., 2013), see Figure 1. In 224 IF, based on vegetable fat, the phospholipids are provided by lecithin, derived from either sunflower seeds or soybeans (Delplanque et al., 2015) and from residual bovine milk fat from skimmed milk powder (Berger et al., 2000). The phospholipids from skimmed milk powder also account for the presence of sphingomyelin, which cannot be sourced via plant-based fat blends.

228 The level of phospholipids varies among IFs, but IFs consist mostly of PC, SM, and PE with 229 lower levels of PI and PS (Braun, Flück, Cotting, Monard, \& Giuffrida, 2010; Fong, Ma, \& Norris, 230 2013).

\subsubsection{Cholesterol}

233 One of the minor components of human and bovine milk lipids are sterols, which make up $0.3 \%$ 234 of total fat. Cholesterol constitutes about $95 \%$ of the total sterols. Human milk is a rich source of 
235 cholesterol, it contains about $90-150 \mathrm{mg} / \mathrm{L}$ of cholesterol (Berger et al., 2000; Koletzko, 2016).

236 Bovine milk fat contains higher levels, around $300 \mathrm{mg} / \mathrm{L}$ of cholesterol (Jensen et al., 1990a), 237 whereas IFs contain 0-4 mg/L of cholesterol (Koletzko, 2016). A recent study investigating sterol 238 contents of IFs showed that IFs based on vegetable fats contained on average $0.185 \mathrm{mg} / \mathrm{L}$ of 239 cholesterol (Claumarchirant, Matencio, Sanchez-Siles, Alegría, \& Lagarda, 2015). In line with 240 the findings on phospholipids, the cholesterol present in IF based on vegetable fats also mostly 241 originates from small amount of milk fat present in skimmed milk (Berger et al., 2000). Newer 242 types of IF, containing a blend of vegetable fats and bovine milk fat, contain higher levels of 243 sterols, on average $0.927 \mathrm{mg} / \mathrm{L}$ (Claumarchirant et al., 2015), which is still surprisingly low.

244 However, the amount of milk fat in these IF products was not specified, so the fraction of bovine 245 milk fat might have been low. Calculations based on literature values (NEVO online) indicate that per addition of $10 \%$ bovine milk fat to a fat blend for infants formula $5.5 \mathrm{mg} / \mathrm{L}$ of cholesterol could be added.

\section{Effects of milk fat related components on infant physiology and health}

250 In recent years, the importance of dietary fats in infant nutrition has gained increasing scientific interest. Rather than merely a source of energy, it has become clear that the composition and structure of dietary fats in the infant diet could have profound influence on infant development, physiology and health. In this section, we will review how; 1) digestion/absorption, 2) metabolic responses, 3) gut immunity, 4) microbiota and 5) cognition could be affected by the composition and structure of milk fat related components. The main effects are illustrated in Figure 2. Since only very few studies have been performed to study the effects of these components in infants, other studies have been included to indicate possible interesting leads for infant health. These effects are indicated with a dotted line in Figure 2. 
262 The fat composition in the diet of infants affects the digestion and absorption of nutrients in

263 infants. A well-studied example is the digestion and absorption of TAGs. During digestion,

264 gastric and pancreatic lipases release the fatty acids positioned at the sn- 1 and sn-3 positions of

265 the TAG. As mentioned in paragraph 2.1.2, in human breast milk, these positions are

266 predominantly occupied by MCFA, long-chain unsaturated fatty acids as well as low levels of

267 butyrate. Butyrate and MCFA are, unlike LCFA, rapidly absorbed in the intestine as free fatty

268 acids (FFA) (Innis, 2011). The sn-2 fatty acid remains on glycerol as sn2-monoglyceride

269 (MAG). In human milk, the most abundant fatty acid in the sn-2 position is palmitic acid. Due

270 to the more polar nature of the sn2-MAG, this fatty acid is more efficiently absorbed in the

271 intestine in the form of sn2-MAG rather than as a FFA (Innis, 2015). In contrast, IF based on

272 vegetable fats mainly has palmitic acid in sn1 and sn3 position, that are released by the

273 digestive lipases, resulting in large amounts of unesterified palmitic acid, as well as other low

274 absorbable FA, freely present in the lumen (Innis, 2011). These long-chain saturated FFA form

275 complexes with calcium ions, generating non-absorbable soaps (Quinlan, Lockton, Irwin, \&

276 Lucas, 1995; Yao et al., 2014a). These calcium soaps are described to be associated with

277 negative effects for infants, such as constipation, stool hardness (Bongers et al., 2007) (Nowacki

278 et al., 2014a) and reduced bone mineralization (Litmanovitz et al., 2013). As described in

279 section 2.1.2 bovine milk and human milk contain respectively 40-45\% (Bracco, 1994) and 70-

280 88\% (Bracco, 1994; López-López et al., 2002; Sun et al., 2018) of the palmitic acid at the sn-2

281 position and therefore less soap formation will most likely occur with IF containing bovine milk

282 fat.

283

284

3.1.2 Cholesterol absorption

285 Cholesterol is a key component in cell membranes, it is important in brain maturation through myelination, and cholesterol is a precursor for bile acids and steroid hormones (Haque,

287 Mozaffar, \& Mozaffor, 1992). Furthermore, cholesterol is an important structural part of 
chylomicrons and lipoproteins, which are key factors for the absorption and transportation of

289 LCFA in the body.

290 As mentioned in section 2.2.2, IFs contain much less cholesterol than human breast milk

291 (Claumarchirant et al., 2015; Huisman et al., 1996). The low amounts of total cholesterol in IF,

292 is most likely the reason for the lower serum levels of total cholesterol and LDL cholesterol

293 found in formula fed infants compared to breast fed infants (Shamir et al., 2003). Furthermore,

294 it could explain the three times higher cholesterol synthesis rate seen in formula fed infants

295 (Cruz et al., 1994), as these infants would have to compensate for the lack of total cholesterol

296 otherwise present in human breast-milk. Studies suggest that supplementing IF with cholesterol,

297 does not entirely correct the lower plasma cholesterol levels found in formula fed neonates or

298 piglets, respectively (Bayley et al., 2002; Rioux \& Innis, 1993). In contrast, Timby et al, showed

299 that MFGM-enriched formula increased cholesterol levels, so at the age of 6 months,

300 cholesterol levels were similar to breast-fed infants (Timby, Lönnerdal, Hernell, \& Domellöf,

301 2014). Although these studies are not directly comparable, these observations may indicate that

302 cholesterol associated with the MFGM is more easily absorbed by the infant intestine than free

303 cholesterol. Another factor which may influence cholesterol absorption in infants is the presence

304 of plant sterols in IF, such as brassicasterol, campesterol, stigmasterol, $\beta$-sitisterol and

305 sitostanol, which are absent in human breast milk (Claumarchirant et al., 2015; Huisman et al.,

306 1996). Total plant sterol levels exceeded the levels of total animal sterols in most formulas,

307 except those with added anhydrous milk fat and/or MFGM, where total animal sterol levels

308 were slightly higher than plant sterol levels (Claumarchirant et al., 2015). Plant sterols have

309 been described to reduce cholesterol intestinal absorption in adults (Alphonse, Ramprasath, \&

310 Jones, 2017; Smet, Mensink, \& Plat, 2012). However, the role of plant sterols in healthy term

311 formula fed infants is unknown and needs to be investigated.

3.1.3 Effect of milk fat globular membrane on digestion and absorption 
314 Bovine milk lipids in IF could also influence digestibility of proteins. In vivo and in vitro

315 studies have shown that adding products including, but not exclusively containing MFGM and

316 bovine milk fat to IF, leads to higher resistance of casein and $\beta$-lactoglobulin to digestion, as

317 compared to formula based on vegetable fats. However, the exact composition and amount of

318 the MFGM ingredients used in these studies are unknown and they may contain a variety of

319 bioactive components. In a "minimally processed" model IF based on dairy fats with native

320 MFG, casein and $\beta$-lactoglobulin were hydrolyzed slower, than the same formula after

321 homogenization and pasteurization in an in vitro digestion system (Bourlieu et al., 2015). A

322 similar reduction in protein digestion was reported in neonatal piglets receiving modified IF

323 containing a mixture of milk and vegetable lipids and MFGM (Le Huërou-Luron et al., 2016).

324 The resulting higher numbers of $\beta$-casein peptides in the gut, may exhibit bioactive functions

325 that accelerates gut maturation (Le Huërou-Luron et al., 2016).

326 Lipolysis is also altered by lipid structure and components that are part of the MFGM, such as

327 polar lipids. For example, the size and interfacial composition of MFG have shown to impact

328 digestibility of lipids in simulated gastro-duodenal digestion (Garcia, Antona, Robert, Lopez, \&

329 Armand, 2014). Replacing polar lipids from soybean with milk polar lipids, changed the blood

330 levels of lipids in mice after meals, with milk polar lipids resulting in a quicker elevation and

331 clearance of plasma TAG (Lecomte et al., 2015). Finally, Mathiassen et al. showed that

332 exchanging soy lecithin with dairy phospholipids increased gastric lipase activity by 2.5 -fold

333 (Mathiassen et al., 2015). Human breast milk contains bile-salt stimulated lipase (BSSL), which

334 accounts for $20-40 \%$ of lipase activity in infants (Koletzko, Agostoni, Bergmann, Ritzenthaler,

$335 \&$ Shamir, 2011). Since this lipase is not present in IF, formula-fed infants lack this extra lipase

336 activity. Thus, the increased gastric lipase activity, when replacing soy lecithin with bovine milk

337 polar lipids, might possibly be beneficial for formula-fed infants. A review about the structure

338 of the milk fat and the relation with digestibility has been published by Bourlieu and Michalski

339 (Bourlieu \& Michalski, 2015). 
342 Generally, the body compositions and growth curves differ between breastfed and formula-fed 343 infants, as breastfed infants tend to have slower weight gain (Dewey, 1998) and breastfeeding

344 shows less association with childhood obesity (Gunnell, Neher, \& Safranek, 2016; Harder,

345 Bergmann, Kallischnigg, \& Plagemann, 2005). These differences on infant growth performance

346 have been linked to protein concentration (and thereby energy density) (Koletzko et al., 2009;

347 Weber et al., 2014) and general feeding practices (Appleton et al., 2018). Nevertheless, there

348 has recently been increasing focus in literature on how the lipid composition of the infant diet

349 influence metabolism and metabolic programing in infants as well.

350

3.2.1 Milk fat globule membrane, cholesterol, polar lipids and metabolic responses

The dietary lipid structure is a focus area within neonatal lipid metabolism research. Both the

353 lipid droplet size, as well as the components of the MFGM, may possibly contribute to the

354 preventive effects of breastfeeding on childhood obesity. Studies in mice have shown, that

355 consumption of pellets with phospholipid-coated large lipid droplets, reduced fat accumulation

356 and improved the metabolic profiles in adult mice (Oosting et al., 2012), and protected against

357 obesity in adult life during a Western-style diet (highly processed, high saturated fat and high

358 carbohydrate content) challenge (Baars et al., 2016). In a clinical study, where infants received a

359 low-energy, low-protein, MFGM-enriched formula, cholesterol levels were normalized to the

360 levels of breast-fed infants, most likely due to the cholesterol in MFGM (Timby, Lönnerdal, et

361 al., 2014). However, there was no difference in growth performance between infants receiving

362 standard or low-energy, low-protein, MFGM-enriched formula (Timby, Domellof, Hernell,

363 Lonnerdal, \& Domellof, 2014).

364 Interestingly, mice fed a high-fat diet rich in polar lipids (phospholipids and sphingolipids) from

365 soybeans, showed white adipose tissue hypertrophy and inflammation. White adipose tissue

366 hypertrophy is indicative of an imbalance in fat metabolism that is associated with obesity

367 mechanisms. This was not observed when the mice were fed a similar high-fat diet based on 
milk polar lipids (Lecomte et al., 2016). In two other studies, feeding mice bovine milk

369 sphingomyelin, compared to egg sphingomyelin, attenuated the consequences of high-fat-

370 induced obesity in mice (Norris, Jiang, Ryan, Porter, \& Blesso, 2016; Norris, Porter, Jiang,

371 Millar, \& Blesso, 2017). More long-term studies on infants are required to elucidate the

372 relationship between MFGM, metabolism and metabolic programming. For a recent review on

373 health-benefits of phospholipids in milk, see Verardo et al (Verardo, Gómez-caravaca, Arráez-

374 román, \& Hettinga, 2017).

375

376

3.2.2 Medium-chain fatty acids and metabolic responses

377 Since MCFA are not dependent on incorporation into the chylomicrons for absorption, MCFA

378 are easily absorbed. Moreover, in contrast to LCFA, MCFA uptake in mitochondria occurs

379 independent of the carnitine shuttling, contributing to a faster oxidation of MCFA (Marten,

380 Pfeuffer, \& Schrezenmeir, 2006). Since the uptake of MCFA is easier, compared to LCFA, IFs

381 for premature born children are enriched with MCFA, in the form of medium-chain triglyceride

382 fats. Consumption of MCFA has been shown to increase diet-induced heat generation and fat

383 oxidation in adults (Kasai et al., 2002; Ogawa et al., 2007; Scalfi, Coltorti, \& Contaldo, 1991),

384 and in preterm infants the consumption of MCT was found to increase energy metabolism and

385 improve thermoregulation (Telliez, Bach, Dewasmes, Leke, \& Libert, 1998; Telliez, Bach,

386 Leke, Chardon, \& Libert, 2002).

387 A few studies on rodents have investigated the impact of infant consumption of MCFA. In rats,

388 high dietary intake of MCFA during pregnancy, prevented obesity in their offspring later in life

389 (Dong et al., 2011). In a study of both rats and mice, increased early-in-life intake of MCFA

390 protected against the negative effects of a high-energy diet in adulthood, such as fat

391 accumulation and insulin sensitivity (Van de Heijning, Oosting, Kegler, \& Van der Beek, 2017).

392 In term infants, the role of MCFA on short- and long-term metabolism remains unclear. 
395 The essential fatty acid linoleic acid (LA) is needed by the body to synthesize arachidonic acid 396 (ARA). Therefore, LA is added to IF in similar levels as found in human milk. The LA levels in 397 commercially available IF are approximately around $16 \%$ of total FA (Table 1), which is similar 398 to the LA levels in today's human milk. During the last 50-60 years the lipid composition in 399 human breast milk has changed, so that today higher concentrations of LA are observed, from 400 about 5\% to 16\% LA (Ailhaud et al., 2006), whereas levels of alpha-linolenic acid (ALA) have 401 remained stable the past 40 years. This has brought up a lot of debate in the scientific field 402 about the optimal level of LA and the optimal ratio with ALA (Gibson, Makrides, Koletzko, 403 Brenna, \& Craig-Schmidt, 2008; Simopoulos et al., 1994). In bovine milk, LA concentrations 404 are approximately 10 times less than in the current human breast milk, 1.44\% (Table 1). Bovine 405 ALA levels are about half of the levels in human milk; $0.49 \%$ and $1.04 \%$, respectively. In recent studies on mice and rats, reducing LA (3.16 energy percentage (en\%) vs $1.36 \mathrm{en} \%$ ) in early life programmed towards relative metabolic resistance to a Western style diet (2.54 en\%) 408 in adult life. In mice, low LA diet (1.36 en\% LA) decreased fat accumulation, reduced fasting 409 TAG levels and lowered fasting leptin levels, whereas in rats a beneficial adipocyte composition 410 was reported (Oosting, Kegler, van de Heijning, Verkade, \& van der Beek, 2015). Furthermore, 411 mice fed a Western-like diet high in LA and low in ALA (LA/ALA ratio 28), showed enhanced 412 fat mass accumulation through four generations (Massiera et al., 2010). To elucidate the role of 413 the ratio and levels of LA and ALA in infant nutrition more future research is required.

\subsection{Gut immunity}

416 The neonatal period is unique, in the sense that this is the time for maturation of the gut immune 417 system and for the establishment of the gut microbiota. At birth, the gastrointestinal tract in 418 humans is immature and adequate stimulation through diet and microbiota is essential for the 419 gut to mature (Davis, Wang, \& Donovan, 2017; M. Wang, Monaco, \& Donovan, 2016). These 420 processes are also influenced by the fat composition of the neonatal diet. 
421 Dietary fats have been linked to host immune responses and have been associated with

422 functions such as gut immune maturation, gut integrity and the establishment of gut immune

423 homeostasis. Several studies have focused on the group of sphingolipids (including

424 sphingomyelin, glycosphingolipids and gangliosides) and their potential protective functions

425 against pathogenic bacteria and toxins, and their impact on gut immune maturation. The topic

426 was recently reviewed by Nilsson (Nilsson, 2016). In particular, sphingosine-1-phosphate

427 (S1P), a metabolite from the degradation of sphingomyelin has gained much interest due to its

428 intestinal immune modelling functions (Kunisawa \& Kiyono, 2012). These include a role in

429 intestinal epithelial cell barrier function, proliferation of IgA producing cells and lymphocyte

430 trafficking, as demonstrated in cell lines (Greenspon et al., 2011). Furthermore, imbalance of

431 S1P may be involved in the development of diseases, which evolve due to inadequate regulation

432 of the intestinal immune response, such as food allergies and intestinal inflammation, as

433 reviewed recently by Kunisawa \& Kiyonon (Kunisawa \& Kiyono, 2016).

434 Besides the effect of sphingolipids, immunomodulatory effects of IF supplemented with bovine

435 MFGM have been reported, in several animal and in vitro models, as well. The maturation of

436 the mucosal immune system was accelerated in piglets receiving MFGM, based on the higher

437 secretion of the immune system mediating cytokine interferon gamma from cells in the lymph

438 nodes lining the small intestinal tissue (mesenteric lymph nodes). The authors indicate that these

439 results might be related to the presence of sphingolipids in the MFGM fraction (Le Huërou-

440 Luron et al., 2016). In some studies, gangliosides reduced proinflammatory signaling in the

441 intestine in an in vitro gut model (Schnabl et al., 2009), whereas others have not observed this

442 effect in preterm piglets (Møller et al., 2011).

443 Butyrate has been shown to have an important function in maintaining intestinal barrier function

444 (Leonel \& Alvarez-Leite, 2012). However, studies on Caco-2 cells have shown that in contrast

445 to $2 \mathrm{mM}$ butyrate, $8 \mathrm{mM}$ butyrate has an adverse effect on a model for intestinal barrier function

446 (Peng, He, Chen, Holzman, \& Lin, 2007). Furthermore, intestinal mucosal injury has been

447 associated with administration of SCFA to young neonatal rats (Nafday et al., 2005). An effect, 
448 which ceases with intestinal maturation. These studies have led to the hypothesis that too much

449 SCFA, as a result of microbial overproduction, may be a cause of necrotizing enterocolitis (a

450 major condition of illness in newborn children) in premature infants (Lin, 2004). However,

451 when butyrate is digested (rather than produced by colonic microbes), butyrate is most likely

452 rapidly absorbed in the upper gastrointestinal tract. The digestion and absorption of butyrate in

453 premature and term infants is not well described in the literature, as this fatty acid is only

454 present in human breast milk in very low levels (see Table 1). Therefore, further investigations

455 are needed to elucidate the health effect of butyrate in bovine milk fat containing IF, since

456 butyrate is digested and expected to be readily absorbed.

457 Clinical studies have shown that supplementing IF with bovine lipid components may

458 potentially prevent some types of infection in infants as well. A fat blend containing bovine

459 MFGM was shown to decrease episodes of bloody diarrhea in Peruvian infants/young children

460 (Zavaleta et al., 2011) and reduce the risk of acute otitis media (middle ear infection) (Timby et

461 al., 2015). On the contrary, a study on rotavirus diarrhea did not show any effect of

462 supplementing IF with a spray-dried ganglioside concentrate (Poppitt et al., 2014) and the study

463 by Timby et al. did not show a reduction in other types of infections. However, both studies

464 were hampered by a low level of background infections. For reviews, see (Hernell et al., 2016;

465 Rueda, 2007).

466

467

3.4 Microbiota

468 Distinct differences are observed in the microbiota between breast-fed and formula-fed infants

469 (Davis et al., 2017; Kashtanova et al., 2016; Le Huërou-Luron, Blat, \& Boudry, 2010) and it is

470 wellknown that the gut microbiome plays a crucial role in the maturation of the gastrointestinal

471 immune defense (Kaplan, Shi, \& Walker, 2011; Stokes, 2017; M. Wang et al., 2016). Key

472 factors modulating the microbiota are the presence of human milk oligosaccharides (Castanys-

473 Muñoz, Martin, \& Vazquez, 2016; Donovan \& Comstock, 2016) and maternal factors (Mueller, 
474 Bakacs, Combellick, Grigoryan, \& Dominguez-Bello, 2015). In addition, the lipid composition

475 of the infant's diet could possibly alter the microbiota composition, as discussed below.

476 SCFA and MCFA are described to exhibit antimicrobial effects against E. coli, Listeria

477 monocytogenes and Staphylococcus aureus in vitro and in vivo (Kelsey, Bayles, Shafii, \&

478 McGuire, 2006; Sprong 1999; ). In particular, caprylic acid (C8:0) has shown inhibitory

479 functions against pathogens, it both reduces bacterial growth in reconstituted IF (Choi, Kim,

480 Lee, \& Rhee, 2013) and weaning mortality in rabbits, fed a diet supplemented with caprylic

481 acid-containing TAGs (Skrivanova, Skrivanova, Volek, \& Marounek, 2009). For a review on

482 dietary fatty acids and food-borne bacterial infections, see Harrison et al. (Harrison, Balan, \&

483 Babu, 2013). This review mainly focuses on effects observed in chickens or cell cultures.

484 Not much is known on the effect of milk fat on microbiota composition. In piglets,

485 supplementing IF with bovine milk fat and MFGM increased Proteobacteria and Bacteroidetes

486 while decreasing Firmicutes phyla, compared to piglets receiving formula exclusively based on

487 vegetable lipids (Le Huërou-Luron et al., 2016).

488 IF with structured vegetable TAGs increased Bifidobacteria and Lactobacillus strains compared

489 to IF containing standard vegetable fats in two clinical intervention studies with a duration of

490 respectively 6 and 8 weeks (Yao et al., 2014a; Yaron et al., 2013).

491 Furthermore, adding gangliosides to IF reduced the levels of fecal E. coli and increased fecal

492 Bifidobacteria in pre-term newborn infants (Rueda, Sabatel, Maldonado, Molina-Font, \& Gil,

493 1998). Although the lipid composition in the diet of neonates indeed does alter gut microbiota,

494 the mechanisms, as well as the effects of milk fat based IF on the microbiota composition in the

495 child needs to be further elucidated.

496

497

3.5 Cognition

498 Population studies have established that even after elimination of socioeconomic factors, breast-

499 fed infants have an advantage over formula-fed infants when measuring cognitive functions

500 (Anderson, Johnstone, \& Remley, 1999; Kramer et al., 2008). Although IFs continuously are 
501 being improved, these data suggest that the nutritional components, composition and structure

502 of IF still needs to be optimized, in order to achieve optimal infant neurodevelopment.

503

504

3.5.1 Cognition and dairy fat components

505 Several individual lipid components present in human breast milk have been shown to be

506 beneficial for brain development, including gangliosides, sphingomyelin and cholesterol. These

507 lipids are all part of the MFGM and are present in lower concentration in IF, than in human

508 breast milk, especially in formulas based entirely on vegetable fats (Claumarchirant et al., 2015;

509 Pan \& Izumi, 2000; B. Wang, Brand-Miller, McVeagh, \& Petocz, 2001; Zeisel, Char, \& Sheard, 510 1986).

511 Clinical studies have demonstrated that supplementing IF with bovine lipid components,

512 including MFGM fraction (Timby, Domellof, et al., 2014), sphingomyelin (Tanaka et al., 2013)

513 and gangliosides (Gurnida, Rowan, Idjradinata, Muchtadi, \& Sekarwana, 2012), improves the

514 cognitive score of infants. Besides clinical trials on infants evaluated by cognitive tests, animal

515 studies have given more insight in the influence of certain lipid components on brain

516 development and cognitive function. In mice, the diet was supplemented with bovine

517 phospholipids to obtain large phospholipids-coated lipid droplets, which improved cognitive

518 performance (Schipper, van Dijk, et al., 2016). Dietary cholesterol (Haque et al., 1992) and

519 sphingomyelin (Oshida et al., 2003) improved brain myelination in mice and rats, respectively,

520 whereas sialic acid supplementation increased the levels of these gangliosides in rat brain

521 (Scholtz, Gottipati, Gajewski, \& Carlson, 2013). Piglets received a diet supplemented with

522 either MFGM, lactoferrin and prebiotics (Mudd et al., 2016) or a combination of bovine

523 phospholipids and gangliosides (Liu et al., 2014), which in both cases induced physiological

524 changes in the brain. Furthermore, mice fed diets supplemented with dairy lipids, were

525 protected against cognitive impairment due to LPS challenge in adulthood (Dinel et al., 2016).

526 

lipids

529 Today, supplementing IF with ARA (from fungus Mortierella alpina) and DHA from either

530 single cell oil (algae) or from fish (tuna) has become common, to ensure adequate levels for 531 normal infant brain development. DHA is essential for normal growth and development of the 532 infant brain, where DHA accumulates during the first years of life (Bernard et al., 2017). Like

533 DHA, ARA is important for infant neurological development and together, DHA and ARA, 534 account for approximately $25 \%$ of fatty acids in the brain (Hadley, Ryan, Forsyth, Gautier, \& 535 Salem, 2016). When using human milk as a golden standard for IF, the ARA addition level 536 should be higher than DHA levels (Koletzko, 2016; Lien, Richard, \& Hoffman, 2017).

537 Irrespective of the fat blend used, DHA and ARA are added as separate ingredients to IF.

538 Recently some studies have investigated whether differences in the dietary fat blends may affect

539 the efficiency of DHA accumulation in the blood cells and ultimately in brain tissues. It has

540 been proposed that a dairy fat matrix enriched in ALA might improve DHA accretion in rodents

541 (Du et al., 2012). It has been suggested that lowering the LA/ARA ratio increase brain DHA, as

542 both compounds compete in the same pathway to be converted from LA to ARA, and ALA

543 through EDA to DHA, respectively. This has been reviewed by Astrup et al. (Astrup et al.,

544 2016). As mentioned before in paragraph 3.2.3, the levels of LA and the ratio with ALA in IF

545 are under debate. In mice, reducing the LA in the maternal diet increased brain n-3 LC-PUFA

546 (ALA, EPA, DPA (C22:5 n-3) and DHA) in the offspring (Schipper, Oosting, Scheurink, van

547 Dijk, \& van der Beek, 2016), whereas increasing ARA in sow diet increased DHA in piglet

548 brains (Bazinet, McMillan, \& Cunnane, 2003). However, this topic is a matter of much debate.

549 In one clinical trial, formulas with lower LA:ALA ratios increased DHA and ARA levels in

550 plasma and erythrocyte phospholipids, but was insufficient to ensure DHA and ARA levels that

551 match the levels of circulation of a breast-fed infant (Makrides, Neumann, Jeffrey, Lien, \&

552 Gibson, 2000). This study did not, however, include dairy fat. 
553 It has been speculated that the high levels of butyric acid and MCFA in dairy fat may possibly

554 spare ALA from oxidation, as energy is generated from the rapid absorption and oxidation of 555 butyric acid and MCFA (Gianni et al., 2018; Jones, 1994). Therefore, bioconversion from ALA 556 to DHA might be favored.

557 Further studies involving infant clinical trials are needed to elucidate the potential cogitative 558 benefits of adding dairy fats to IF.

559

5604 Advantages and drawbacks of different fat source for IF

561 In this review, we have discussed the different components of bovine milk fat, and compared

562 those to human milk fat and vegetable fat. Furthermore, we have reviewed the existing evidence 563 from both clinical trials and animal studies, on how bovine milk fat impacts (infant) physiology 564 and health. Based on this, we would like to highlight some of the advantages and drawbacks of 565 different fat sources for IF.

566 Bovine milk fat contains valuable lipids, such as cholesterol, phospholipids and sphingolipids.

567 These lipids are present in human milk, but cannot be obtained from vegetable sources (see 568 paragraph 2.2). Although more research is needed, these components seem to have several 569 beneficial effects on infant physiology and health, as discussed in this review. Furthermore, 570 bovine milk fat contains a high variety of TAGs, with a high percentage of palmitic acid 571 positioned at the sn-2 position, which is also the case in human milk (Bracco, 1994; López-

572 López et al., 2002; Sun et al., 2018). It has been shown that a high percentage of palmitic acid at 573 sn-2 could positively affect TAG digestion and absorption in infants, as well as the comfort of 574 infants (Bongers et al., 2007; Nowacki et al., 2014b; Quinlan et al., 1995; Yao et al., 2014b). So 575 in contrast to that what was thought in the 1960s (Fomon, 2001b), addition of bovine milk fat to 576 IF might decrease constipation instead of causing it.

577 However, bovine milk fat cannot be used as a single source of lipids, as it contains higher levels 578 of saturated fatty acids compared to human milk fat and lower levels of LCFA (LA and ALA) 579 and DHA and ARA (Table 1). Because of the low levels of LA in bovine milk fat, adding 
580 vegetable fat is necessary to reach the required level of LA. A maximum of $67 \%$ of bovine milk

581 fat can currently be used in IF, when using todays preferred LA levels. These LA levels are

582 based on current breast milk levels. However, LA levels can be lowered from an average of

$58316 \mathrm{~g} / 100 \mathrm{~g}$ fatty acids to about $6 \mathrm{~g} / 100 \mathrm{~g}$ fatty acids without challenging current Codex

584 Alimentarius legislation (FAO) (Commission, 2011). The minimum level LA required, reflects

585 the levels of LA in human milk at the start of industrialization, and preclinical studies indicate

586 that lowering the LA levels may possibly have a positive impact of infant health (Massiera et

587 al., 2010; Oosting et al., 2015).

588 In addition, bovine milk fat contains butyrate, which only is present in trace amounts in human

589 milk, as well as elevated levels of MCFA (Table 1). Most likely, these components are rapidly

590 absorbed and metabolized in infants. However, the nutritional needs of infants are complex

591 matters, and although no adverse effects in infants have been reported on neither butyrate nor

592 MCFA, the effect of elevated levels in IF on infant health and development remains unknown.

593

594 Vegetable fats can be blended in such a way, that they represent the fatty acid profile of human

595 milk. This human milk profile includes some of the valuable LCFA (LA and ALA), which only

596 can be obtained in low amounts from bovine milk fat. However, the structure of vegetable

597 TAGs differ from that of human milk, which results in suboptimal digestion of specific

598 triglycerides. To address this problem, vegetable fats can be re-structured by industrial

599 processing. Thereby, a TAG structure with more palmitic acid in the sn- 2 position can be

600 obtained. Still, the overall TAG composition is less diverse compared to human and bovine milk

601 fat TAGs.

602 A commonly used vegetable fat is palm oil, although some commercial parties avoid the

603 inclusion of palm oil in IF (Leite et al., 2013; Lloyd et al., 1999; Oliveira De Souza et al., 2017).

604 The latter is due to concerns related to digestion (discussed above), unsustainable production

605 methods, and the presence of elevated levels of processing-induced contaminants in palm oil

606 (i.e. glycidol esters and 3-monochloro-1,2-propanediol (3-MCPD-esters)) which are known to 
607 have adverse health effects (IARC Working Group on the Evaluation of Carcinogenic Risks to

608 Humans, 2013). However, when palm oil is avoided, the level of palmitic acid, one of the most

609 abundant FA in human milk, is very low (Table 1). Another possible concern is the presence of

610 plant sterols in vegetable fats, which are not present in human milk. Although this issue has

611 gained little attention, it deserves further investigation

612

613 The use of fat blends containing both bovine milk fat and vegetable fats seems to be a good

614 solution for making the best possible IF. This will provide infants with both the valuable bovine

615 milk lipids, which cannot be obtained from vegetable fats, as well as the necessary LCFA

616 profile by adding vegetable fats. Furthermore, combined bovine milk and vegetable fat blends

617 allow the production of palm oil-free fat blends with the same palmitic acid level as observed in

618 human milk (Table 1). Independent on the major fat source used for IF, DHA and ARA are

619 always added separately to the chosen fat blend to accomplish their preferred fatty acid

620 composition.

621 Although the levels of palmitic acid at the sn-2 position is higher in IF's containing either

622 bovine milk fat or structured vegetable TAGs, the levels of palmitic acid at sn-2 of human milk

623 is still not reached in the current IFs (see Table 2). Addition of structured vegetable TAGs to a

624 blend with bovine milk fat and vegetable fat opens new possibilities to increase the sn-2

625 percentages, and to get closer to the TAG composition of human milk. Another possibility to

626 improve IF is the generation of phospholipid coated droplets. A disadvantage of all current fat

627 blends is that, due to processing, all fat droplets have the same globule size. This is unlike

628 human milk fat, which contains larger globules in varying sizes. A new concept has emerged, in

629 which larger phospholipid coated droplets are produced (Gallier et al., 2015). These artificial

630 lipid droplets are closer to human MFG than regular produced infant formula, since they have a

631 more comparable particle size with human milk fat, compared to normal IF lipid droplets, and

632 they contain bovine MFGM components at their membrane (Gallier et al., 2015). However,

633 these globules contain TAGs from vegetable fat, which are structurally different from human 
634 milk fat. Probably, it would be more optimal if both the membrane components, globule size

635 and TAG composition and structure would more closely resemble the composition of human

636 milk fat.

637

638

6395 Future perspectives

640 In this review we have pointed out several health effects of bovine milk lipids. Still, the health

641 impact of some bovine lipids have not been studied in infants yet. Although butyrate is well-

642 known to be produced by the microbiota in the lower gastrointestinal tract, the health effects of

643 butyrate in IF needs to be studied. Furthermore, MCFA, as MCT fats, are known to affect

644 metabolism. But more dedicated research is needed to elucidate how elevated MCFA levels in

645 TAGs influence infant health. Clinical trials on MFGM do not always specify the dose and

646 composition of the MFGM components used. Therefore, more research is needed to understand

647 which specific MFGM components trigger the health effects that were found.

648

649 An alternative way to use bovine milk fat in IF in the future would be to use MFG with the milk

650 fat globular membrane intact. Today, this is not possible due to the processing techniques used

651 to produce IF powder, such as homogenization and spray drying. Recent work indicates that

652 pasteurization after microfiltration may be a more gentle approach (Hansen et al., 2018). Mild

653 processing seems to be a promising option to maintain bioactivity and structure of the milk

654 components, but extensive research is required to identify technological options maintaining the

655 nativity of the milk ingredients in a safe manner concerning microbiology. Technical

656 possibilities include low heating, low or no homogenization, UV-C irradiation instead of

657 pasteurization and alternative ways of (spray) drying. Current legislation does not allow the use

658 of non-pasteurized milk for IF production, which makes collaboration between regulatory

659 bodies and science a crucial part of any progress to take place in the future. However, recent

660 investigations suggests that inactivation of bioactive components through donor human milk 
661 pasteurization is a key factor influencing growth performance in preterm infants (Li et al., 2017,

662 2018). Interestingly, UV-C treatment seem a promising alternative (Li et al., 2017).

663

664 In conclusion, inclusion of bovine milk fat in IF may bring additional health benefits to infant

665 nutrition, as it delivers a variety of different components, which are present in human milk, but

666 are lacking in vegetable fats. Hence, blending bovine milk fat with vegetable fat in combination

667 with the development of more gentle processing techniques might be a future direction to

668 improve IF.

669

670 Acknowledgements

671 We want to thank R.D. van Anholt (FrieslandCampina Ingredients) for critically reviewing the 672 manuscript.

673

674 


\section{References}

Ailhaud, G., Massiera, F., Weill, P., Legrand, P., Alessandri, J.-M., \& Guesnet, P. (2006). Temporal changes in dietary fats: role of $n-6$ polyunsaturated fatty acids in excessive adipose tissue development and relationship to obesity. Progress in Lipid Research, 45(3), 203-36. https://doi.org/10.1016/j.plipres.2006.01.003

Alphonse, P. A. S., Ramprasath, V., \& Jones, P. J. H. (2017). Effect of dietary cholesterol and plant sterol consumption on plasma lipid responsiveness and cholesterol trafficking in healthy individuals. British Journal of Nutrition, 117(1), 56-66. https://doi.org/10.1017/S0007114516004530

Álvarez, C. A., \& Akoh, C. C. (2016). Preparation of Infant Formula Fat Analog Containing Capric Acid and Enriched with DHA and ARA at the sn-2 Position. Journal of the American Oil Chemists'Society, 93(4), 531-542. https://doi.org/10.1007/s11746-016$2788-7$

Anderson, J. W., Johnstone, B. M., \& Remley, D. T. (1999). Breast-feeding and cognitive development: a meta-analysis. The American Journal of Clinical Nutrition, 70(4), 525-35. Retrieved from http://www.ncbi.nlm.nih.gov/pubmed/10500022

Appleton, J., Russell, C. G., Laws, R., Fowler, C., Campbell, K., \& Denney-Wilson, E. (2018). Infant formula feeding practices associated with rapid weight gain: A systematic review. Maternal \& Child Nutrition, e12602. https://doi.org/10.1111/mon.12602

Astrup, A., Rice Bradley, B. H., Brenna, J. T., Delplanque, B., Ferry, M., \& Torres-Gonzalez, M. (2016). Regular-Fat Dairy and Human Health: A Synopsis of Symposia Presented in Europe and North America (2014-2015). Nutrients, 8(8), 463.

https://doi.org/10.3390/nu8080463

Baars, A., Oosting, A., Engels, E., Kegler, D., Kodde, A., Schipper, L., ... van der Beek, E. M. (2016). Milk fat globule membrane coating of large lipid droplets in the diet of young mice prevents body fat accumulation in adulthood. British Journal of Nutrition, 1-8. https://doi.org/10.1017/S0007114516001082 
Bar-Yoseph, F., Lifshitz, Y., \& Cohen, T. (2013). Review of sn-2 palmitate oil implications for infant health. Prostaglandins Leukotrienes and Essential Fatty Acids, 89(4), 139-143. https://doi.org/10.1016/j.plefa.2013.03.002

Barreiro, R., Regal, P., López-Racamonde, O., Cepeda, A., \& Fente, C. A. (2017). Comparison of the fatty acid profile of Spanish infant formulas and Galician women breast milk. Journal of Physiology and Biochemistry, 1-12. https://doi.org/10.1007/s13105-017-0580-2

Bayley, T. M., Alasmi, M., Thorkelson, T., Jones, P. J. H., Corcoran, J., Krug-Wispe, S., \& Tsang, R. C. (2002). Longer term effects of early dietary cholesterol level on synthesis and circulating cholesterol concentrations in human infants. Metabolism: Clinical and Experimental, 51(1), 25-33. Retrieved from http://www.ncbi.nlm.nih.gov/pubmed/11782868

Bazinet, R. P., McMillan, E. G., \& Cunnane, S. C. (2003). Dietary alpha-linolenic acid increases the n-3 PUFA content of sow's milk and the tissues of the suckling piglet. Lipids, 38(10), 1045-9. Retrieved from http://www.ncbi.nlm.nih.gov/pubmed/14669969

Berger, A., Fleith, M., \& Crozier, G. (2000). Nutritional Implications of Replacing Bovine Milk Fat With Vegetable Oil in Infant Formulas. Journal of Pediatric Gastroenterology and Nutrition, 30(2), 115-130. Retrieved from http://ovidsp.ovid.com/ovidweb.cgi?T $=J S \& P A G E=$ reference $\& D=$ med4\&NEWS=N\&AN $=10697128$

Bernard, J. Y., Armand, M., Peyre, H., Garcia, C., Forhan, A., De Agostini, M., ... EDEN Mother-Child Cohort Study Group (Etude des Déterminants pré- et postnatals précoces du développement et de la santé de l'Enfant). (2017). Breastfeeding, Polyunsaturated Fatty Acid Levels in Colostrum and Child Intelligence Quotient at Age 5-6 Years. The Journal of Pediatrics. https://doi.org/10.1016/j.jpeds.2016.12.039

Bongers, M. E., de Lorijn, F., Reitsma, J. B., Groeneweg, M., Taminiau, J. A., \& Benninga, M. A. (2007). The clinical effect of a new infant formula in term infants with constipation: a double-blind, randomized cross-over trial. Nutrition Journal, 6(1), 8. 
https://doi.org/10.1186/1475-2891-6-8

Bourlieu, C., Ménard, O., De La Chevasnerie, A., Sams, L., Rousseau, F., Madec, M.-N., ... Dupont, D. (2015). The structure of infant formulas impacts their lipolysis, proteolysis and disintegration during in vitro gastric digestion. Food Chemistry, 182, 224-235. https://doi.org/10.1016/j.foodchem.2015.03.001

Bourlieu, C., \& Michalski, M.-C. (2015). Structure-function relationship of the milk fat globule. Current Opinion in Clinical Nutrition and Metabolic Care, 18(2), 118-127. https://doi.org/10.1097/MCO.0000000000000138

Bracco, U. (1994). Effect structure on fat absorption1. American Journal of Clinical Nutrition, $60,1002 \mathrm{~S}-9 \mathrm{~S}$.

Braun, M., Flück, B., Cotting, C., Monard, F., \& Giuffrida, F. (2010). Quantification of Phospholipids in Infant Formula and Growing Up Milk by High-Performance Liquid Chromatography with Evaporative Light Scattering Detector. JOURNAL OF AOAC INTERNATIONAL, 93(3), 948-955.

Castanys-Muñoz, E., Martin, M. J., \& Vazquez, E. (2016). Building a Beneficial Microbiome from Birth. Advances in Nutrition (Bethesda, Md.), 7(2), 323-30. https://doi.org/10.3945/an.115.010694

Choi, M. J., Kim, S. A., Lee, N. Y., \& Rhee, M. S. (2013). New decontamination method based on caprylic acid in combination with citric acid or vanillin for eliminating Cronobacter sakazakii and Salmonella enterica serovar Typhimurium in reconstituted infant formula. International Journal of Food Microbiology, 166(3), 499-507. https://doi.org/10.1016/j.ijfoodmicro.2013.08.016

Cilla, A., Diego Quintaes, K., Barberá, R., \& Alegría, A. (2016). Phospholipids in Human Milk and Infant Formulas: Benefits and Needs for Correct Infant Nutrition. Critical Reviews in Food Science and Nutrition, 56(11), 1880-1892.

https://doi.org/10.1080/10408398.2013.803951

Claumarchirant, L., Matencio, E., Sanchez-Siles, L. M., Alegría, A., \& Lagarda, M. J. (2015). 
Sterol Composition in Infant Formulas and Estimated Intake. Journal of Agricultural and Food Chemistry, 63(32), 7245-7251. https://doi.org/10.1021/acs.jafc.5b02647

Commission, C. A. (2011). STANDARD FOR INFANT FORMULA AND FORMULAS FOR SPECIAL MEDICAL PURPOSES INTENDED FOR INFANTS CODEX STAN 72 - 1981. Formerly CAC/RS 72-1972. Adopted as a world-wide Standard 1981. Amended 1983, 1985, 1987. Revision 2007. Amended 2011.

Contarini, G., \& Povolo, M. (2013). Phospholipids in milk fat: composition, biological and technological significance, and analytical strategies. International Journal of Molecular Sciences, 14(2), 2808-31. https://doi.org/10.3390/ijms14022808

Cruz-Hernandez, C., Goeuriot, S., Giuffrida, F., Thakkar, S. K., \& Destaillats, F. (2013). Direct quantification of fatty acids in human milk by gas chromatography. Journal of Chromatography A, 1284, 174-179. https://doi.org/10.1016/j.chroma.2013.01.094

Cruz, M. L. A., Wong, W. W., Mimouni, F., Hachey, D. L., Setchell, K. D. R., Klein, P. D., \& Tsang, R. C. (1994). Effects of Infant Nutrition on Cholesterol Synthesis Rates. Pediatric Research, 35(2), 135-140. https://doi.org/10.1203/00006450-199402000-00001

Daud, A. Z., Mohd-Esa, N., Azlan, A., \& Chan, Y. M. (2013). The trans fatty acid content in human milk and its association with maternal diet among lactating mothers in Malaysia. Asia Pacific Journal of Clinical Nutrition, 22(3), 431-442. https://doi.org/10.6133/apjen.2013.22.3.09

Davis, E. C., Wang, M., \& Donovan, S. M. (2017). The role of early life nutrition in the establishment of gastrointestinal microbial composition and function. Gut Microbes, 1-29. https://doi.org/10.1080/19490976.2016.1278104

Delplanque, B., Gibson, R., Koletzko, B., Lapillonne, A., \& Strandvik, B. (2015). Lipid Quality in Infant Nutrition. Journal of Pediatric Gastroenterology and Nutrition, 1. https://doi.org/10.1097/MPG.0000000000000818

Dewettinck, K., Rombaut, R., Thienpont, N., Le, T. T., Messens, K., \& Van Camp, J. (2008). Nutritional and technological aspects of milk fat globule membrane material. International 
Dairy Journal, 18(5), 436-457. https://doi.org/10.1016/j.idairyj.2007.10.014

Dewey, K. G. (1998). Growth characteristics of breast-fed compared to formula-fed infants. Biology of the Neonate, 74(2), 94-105. Retrieved from http://www.ncbi.nlm.nih.gov/pubmed/9691152

Dinel, A. L., Rey, C., Baudry, C., Fressange-Mazda, C., Le Ruyet, P., Nadjar, A., ... Layé, S. (2016). Enriched dairy fat matrix diet prevents early life lipopolysaccharide-induced spatial memory impairment at adulthood. Prostaglandins, Leukotrienes and Essential Fatty Acids (PLEFA), 113, 9-18. https://doi.org/10.1016/j.plefa.2016.08.013

Dong, Y.-M., Li, Y., Ning, H., Wang, C., Liu, J.-R., \& Sun, C.-H. (2011). High dietary intake of medium-chain fatty acids during pregnancy in rats prevents later-life obesity in their offspring. The Journal of Nutritional Biochemistry, 22(8), 791-797. https://doi.org/10.1016/j.jnutbio.2010.07.006

Donovan, S. M., \& Comstock, S. S. (2016). Human Milk Oligosaccharides Influence Neonatal Mucosal and Systemic Immunity. Annals of Nutrition and Metabolism, 69(2), 42-51. https://doi.org/10.1159/000452818

Dorni, C., Sharma, P., Saikia, G., \& Longvah, T. (2018). Fatty acid profile of edible oils and fats consumed in India. Food Chemistry, 238, 9-15. https://doi.org/10.1016/J.FOODCHEM.2017.05.072

Du, Q., Martin, J.-C., Agnani, G., Pages, N., Leruyet, P., Carayon, P., \& Delplanque, B. (2012). Dairy fat blends high in $\alpha$-linolenic acid are superior to n-3 fatty-acid-enriched palm oil blends for increasing DHA levels in the brains of young rats. The Journal of Nutritional Biochemistry, 23(12), 1573-1582. https://doi.org/10.1016/j.jnutbio.2011.10.011

EFSA Panel on Dietetic Products Nutrition and Allergies (NDA). (2014). Scientific Opinion on the essential composition of infant and follow-on formulae. EFSA Journal (Vol. 12).

Fomon, S. J. (2001a). Infant Feeding in the 20th Century: Formula and Beikost. The Journal of Nutrition, 131(2), 409S-420S. https://doi.org/10.1093/jn/131.2.409S

Fomon, S. J. (2001b). Infant Feeding in the 20th Century: Formula and Beikost. The Journal of 
Nutrition, 131(2), 409S-420S. https://doi.org/10.1093/jn/131.2.409S

Fong, B., Ma, L., \& Norris, C. (2013). Analysis of Phospholipids in Infant Formulas Using High Performance Liquid Chromatography-Tandem Mass Spectrometry. Journal of Agricultural and Food Chemistry, 61(4), 858-865. https://doi.org/10.1021/jf304877k

Gallier, S., Vocking, K., Post, J. A., Van De Heijning, B., Acton, D., Van Der Beek, E. M., \& Van Baalen, T. (2015). A novel infant milk formula concept: Mimicking the human milk fat globule structure. Colloids and Surfaces. B, Biointerfaces, 136, 329-39. https://doi.org/10.1016/j.colsurfb.2015.09.024

Garcia, C., Antona, C., Robert, B., Lopez, C., \& Armand, M. (2014). The size and interfacial composition of milk fat globules are key factors controlling triglycerides bioavailability in simulated human gastro-duodenal digestion. Food Hydrocolloids, 35, 494-504. https://doi.org/10.1016/j.foodhyd.2013.07.005

Ghosh, M., Sengupta, A., Bhattacharyya, D. K., \& Ghosh, M. (2016). Preparation of human milk fat analogue by enzymatic interesterification reaction using palm stearin and fish oil. Journal of Food Science and Technology, 53(4), 2017-24. https://doi.org/10.1007/s13197$016-2180-5$

Gianni, M. L., Roggero, P., Baudry, C., Fressange-Mazda, C., Galli, C., Agostoni, C., ... Mosca, F. (2018). An infant formula containing dairy lipids increased red blood cell membrane Omega 3 fatty acids in 4 month-old healthy newborns: a randomized controlled trial. BMC Pediatrics, 18. https://doi.org/10.1186/s12887-018-1047-5

Gibson, R., Makrides, M., Koletzko, B., Brenna, T., \& Craig-Schmidt, M. (2008). ISSFAL Statement on Dietary Fats in Infant Nutrition (May 2008). Retrieved from http://archive.issfal.org/statements/pufa-recommendations/statement-2

Giuffrida, F., Cruz-Hernandez, C., Bertschy, E., Fontannaz, P., Masserey Elmelegy, I., Tavazzi, I., ... Wang, P. (2016). Temporal Changes of Human Breast Milk Lipids of Chinese Mothers. Nutrients, 8(11). https://doi.org/10.3390/nu8110715

Glew, R. H., Huang, Y. S., Vander Jagt, T. A., Chuang, L. T., Bhatt, S. K., Magnussen, M. A., 
\& VanderJagt, D. J. (2001). Fatty acid composition of the milk lipids of Nepalese women: correlation between fatty acid composition of serum phospholipids and melting point. Prostaglandins, Leukotrienes, and Essential Fatty Acids, 65(3), 147-56. https://doi.org/10.1054/plef.2001.0303

Greenspon, J., Li, R., Xiao, L., Rao, J. N., Sun, R., Strauch, E. D., ... Turner, D. J. (2011). Sphingosine-1-Phosphate Regulates the Expression of Adherens Junction Protein ECadherin and Enhances Intestinal Epithelial Cell Barrier Function. Digestive Diseases and Sciences, 56(5), 1342-1353. https://doi.org/10.1007/s10620-010-1421-0

Gunnell, L., Neher, J., \& Safranek, S. (2016). Clinical Inquiries: Does breastfeeding affect the risk of childhood obesity? The Journal of Family Practice, 65(12), 931-932. Retrieved from http://www.ncbi.nlm.nih.gov/pubmed/28149981

Gurnida, D. A., Rowan, A. M., Idjradinata, P., Muchtadi, D., \& Sekarwana, N. (2012). Association of complex lipids containing gangliosides with cognitive development of 6month-old infants. Early Human Development, 88(8), 595-601. https://doi.org/10.1016/j.earlhumdev.2012.01.003

Hadley, K. B., Ryan, A. S., Forsyth, S., Gautier, S., \& Salem, N. (2016). The essentiality of arachidonic acid in infant development. Nutrients, 8(4). https://doi.org/10.3390/nu8040216

Hansen, S. F., Petrat-Melin, B., Rasmussen, J. T., Larsen, L. B., Ostenfeld, M. S., \& Wiking, L. (2018). Placing pasteurisation before or after microfiltration impacts the protein composition of milk fat globule membrane material. International Dairy Journal, 81, 3541. https://doi.org/10.1016/J.IDAIRYJ.2017.12.015

Haque, Z. U., Mozaffar, Z., \& Mozaffor, Z. (1992). Importance of dietary cholesterol for the maturation of mouse brain myelin. Bioscience, Biotechnology, and Biochemistry, 56(8), 1351-4. Retrieved from http://www.ncbi.nlm.nih.gov/pubmed/1369207

Harder, T., Bergmann, R., Kallischnigg, G., \& Plagemann, A. (2005). Duration of Breastfeeding and Risk of Overweight: A Meta-Analysis. American Journal of Epidemiology, 162(5), 397-403. https://doi.org/10.1093/aje/kwi222 
Harrison, L. M., Balan, K. V, \& Babu, U. S. (2013). Dietary fatty acids and immune response to food-borne bacterial infections. Nutrients, 5(5), 1801-22.

https://doi.org/10.3390/nu5051801

Hernell, O., Timby, N., Domellöf, M., \& Lönnerdal, B. (2016). Clinical Benefits of Milk Fat Globule Membranes for Infants and Children. The Journal of Pediatrics, 173, S60-S65. https://doi.org/10.1016/j.jpeds.2016.02.077

Huisman, M., van Beusekom, C. M., Lanting, C. I., Nijeboer, H. J., Muskiet, F. A., \& Boersma, E. R. (1996). Triglycerides, fatty acids, sterols, mono- and disaccharides and sugar alcohols in human milk and current types of infant formula milk. European Journal of Clinical Nutrition, 50(4), 255-60. Retrieved from http://www.ncbi.nlm.nih.gov/pubmed/8730614

IARC Working Group on the Evaluation of Carcinogenic Risks to Humans, I. W. G. on the E. of C. R. to. (2013). Some chemicals present in industrial and consumer products, food and drinking-water. IARC Monographs on the Evaluation of Carcinogenic Risks to Humans, 101, 9-549. Retrieved from http://www.ncbi.nlm.nih.gov/pubmed/24772663

Innis, S. M. (2011). Dietary Triacylglycerol Structure and Its Role in Infant Nutrition. Advances in Nutrition: An International Review Journal, 2(3), 275-283. https://doi.org/10.3945/an.111.000448

Innis, S. M. (2015). Palmitic Acid in Early Human Development. Critical Reviews in Food Science and Nutrition, 8398(April), 37-41. https://doi.org/10.1080/10408398.2015.1018045

Institute of Medicine. (2004). Infant formula: Evaluating the Safety of New Ingredients. In Infant Formula: Evaluating the Safety of New Ingredients. Washington(DC): National Academies Press (US). Retrieved from https://www.ncbi.nlm.nih.gov/books/NBK215837/ Jensen, R. G. (2002). The composition of bovine milk lipids: January 1995 to December 2000. Journal of Dairy Science, 85(2), 295-350. https://doi.org/10.3168/jds.S00220302(02)74079-4 
Jensen, R. G., Ferris, A. M., Lammi-Keefe, C. J., \& Henderson, R. a. (1990a). Lipids of bovine and human milks: a comparison. Journal of Dairy Science, 73(2).

https://doi.org/10.3168/jds.S0022-0302(90)78666-3

Jensen, R. G., Ferris, A. M., Lammi-Keefe, C. J., \& Henderson, R. A. (1990b). Lipids of bovine and human milks: a comparison. Journal of Dairy Science, 73(2), 223-40. https://doi.org/10.3168/jds.S0022-0302(90)78666-3

Jensen, R. G., Ferris, a M., Lammi-Keefe, C. J., \& Henderson, R. a. (1990c). Lipids of bovine and human milks: a comparison. Journal of Dairy Science, 73(2), 223-240.

Jiang, J., Wu, K., Yu, Z., Ren, Y., Zhao, Y., Jiang, Y., ... Li, D. (2016). Changes in fatty acid composition of human milk over lactation stages and relationship with dietary intake in Chinese women. Food \& Function, 7(7), 3154-3162.

https://doi.org/10.1039/C6FO00304D

Jones, P. J. (1994). Dietary linoleic, alpha-linolenic and oleic acids are oxidized at similar rates in rats fed a diet containing these acids in equal proportions. Lipids, 29(7), 491-5.

Retrieved from http://www.ncbi.nlm.nih.gov/pubmed/7968270

Kaplan, J. L., Shi, H. N., \& Walker, W. A. (2011). The Role of Microbes in Developmental Immunologic Programming. Pediatric Research, 69(6), 465-472.

https://doi.org/10.1203/PDR.0b013e318217638a

Kasai, M., Nosaka, N., Maki, H., Suzuki, Y., Takeuchi, H., Aoyama, T., ... Kondo, K. (2002). Comparison of diet-induced thermogenesis of foods containing medium- versus longchain triacylglycerols. Journal of Nutritional Science and Vitaminology, 48(6), 536-540. https://doi.org/10.3177/jnsv.48.536

Kashtanova, D. A., Popenko, A. S., Tkacheva, O. N., Tyakht, A. B., Alexeev, D. G., \& Boytsov, S. A. (2016). Association between the gut microbiota and diet: Fetal life, early childhood, and further life. Nutrition (Burbank, Los Angeles County, Calif.), 32(6), 620-7. https://doi.org/10.1016/j.nut.2015.12.037

Kay, J. K., Weber, W. J., Moore, C. E., Bauman, D. E., Hansen, L. B., Chester-Jones, H., ... 
Baumgard, L. H. (2005). Effects of Week of Lactation and Genetic Selection for Milk Yield on Milk Fatty Acid Composition in Holstein Cows. Journal of Dairy Science, 88(11), 3886-3893. https://doi.org/10.3168/jds.S0022-0302(05)73074-5

Kelsey, J. A., Bayles, K. W., Shafii, B., \& McGuire, M. A. (2006). Fatty acids and monoacylglycerols inhibit growth ofStaphylococcus aureus. Lipids, 41(10), 951-961. https://doi.org/10.1007/s11745-006-5048-z

Koletzko, B. (2016). Human Milk Lipids. Annals of Nutrition and Metabolism, 69(2), 28-40. https://doi.org/10.1159/000452819

Koletzko, B., Agostoni, C., Bergmann, R., Ritzenthaler, K., \& Shamir, R. (2011). Physiological aspects of human milk lipids and implications for infant feeding: a workshop report. Acta Paediatrica, 100(11), 1405-1415. https://doi.org/10.1111/j.1651-2227.2011.02343.x

Koletzko, B., von Kries, R., Closa, R., Escribano, J., Scaglioni, S., Giovannini, M., ... European Childhood Obesity Trial Study Group. (2009). Lower protein in infant formula is associated with lower weight up to age $2 \mathrm{y}$ : a randomized clinical trial. The American Journal of Clinical Nutrition, 89(6), 1836-45. https://doi.org/10.3945/ajcn.2008.27091

Kramer, M. S., Aboud, F., Mironova, E., Vanilovich, I., Platt, R. W., Matush, L., ... Promotion of Breastfeeding Intervention Trial (PROBIT) Study Group. (2008). Breastfeeding and Child Cognitive Development. Archives of General Psychiatry, 65(5), 578. https://doi.org/10.1001/archpsyc.65.5.578

Kumar, H., du Toit, E., Kulkarni, A., Aakko, J., Linderborg, K. M., Zhang, Y., ... Salminen, S. (2016). Distinct Patterns in Human Milk Microbiota and Fatty Acid Profiles Across Specific Geographic Locations. Frontiers in Microbiology, 7, 1619. https://doi.org/10.3389/fmicb.2016.01619

Kunisawa, J., \& Kiyono, H. (2012). Immunological Function of Sphingosine 1-Phosphate in the Intestine. Nutrients, 4(12), 154-166. https://doi.org/10.3390/nu4030154

Kunisawa, J., \& Kiyono, H. (2016). Sphingolipids and Epoxidized Lipid Metabolites in the Control of Gut Immunosurveillance and Allergy. Frontiers in Nutrition, 3, 3. 
https://doi.org/10.3389/fnut.2016.00003

Le Huërou-Luron, I., Blat, S., \& Boudry, G. (2010). Breast- v. formula-feeding: impacts on the digestive tract and immediate and long-term health effects. Nutrition Research Reviews, 23(1), 23-36. https://doi.org/10.1017/S0954422410000065

Le Huërou-Luron, I., Bouzerzour, K., Ferret-Bernard, S., Ménard, O., Le Normand, L., Perrier, C., ... Dupont, D. (2016). A mixture of milk and vegetable lipids in infant formula changes gut digestion, mucosal immunity and microbiota composition in neonatal piglets. European Journal of Nutrition. https://doi.org/10.1007/s00394-016-1329-3

Lecomte, M., Bourlieu, C., Meugnier, E., Penhoat, A., Cheillan, D., Pineau, G., ... Michalski, M.-C. (2015). Milk Polar Lipids Affect In Vitro Digestive Lipolysis and Postprandial Lipid Metabolism in Mice. Journal of Nutrition, 145(8), 1770-1777. https://doi.org/10.3945/jn.115.212068

Lecomte, M., Couëdelo, L., Meugnier, E., Plaisancié, P., Létisse, M., Benoit, B., ... Michalski, M. C. (2016). Dietary emulsifiers from milk and soybean differently impact adiposity and inflammation in association with modulation of colonic goblet cells in high-fat fed mice. Molecular Nutrition and Food Research, 60(3), 609-620. https://doi.org/10.1002/mnfr.201500703

Leite, M. E. de Q., Lasekan, J., Baggs, G., Ribeiro, T., Menezes-Filho, J., Pontes, M., ... CostaRibeiro Jr, H. (2013). Calcium and fat metabolic balance, and gastrointestinal tolerance in term infants fed milk-based formulas with and without palm olein and palm kernel oils: a randomized blinded crossover study. BMC Pediatrics, 24(13), 215. Retrieved from http://www.biomedcentral.com/1471-2431/13/215

Leonel, A. J., \& Alvarez-Leite, J. I. (2012). Butyrate. Current Opinion in Clinical Nutrition and Metabolic Care, 15(5), 474-479. https://doi.org/10.1097/MCO.0b013e32835665fa

Li, Y., Nguyen, D. N., de Waard, M., Christensen, L., Zhou, P., Jiang, P., ... Sangild, P. T. (2017). Pasteurization Procedures for Donor Human Milk Affect Body Growth, Intestinal Structure, and Resistance against Bacterial Infections in Preterm Pigs. The Journal of 
Nutrition, 147(6), 1121-1130. https://doi.org/10.3945/jn.116.244822

Li, Y., Nguyen, D. N., Obelitz-Ryom, K., Andersen, A. D., Thymann, T., Chatterton, D. E. W., ... Sangild, P. T. (2018). Bioactive Whey Protein Concentrate and Lactose Stimulate Gut Function in Formula-fed Preterm Pigs. Journal of Pediatric Gastroenterology and Nutrition, 66(1), 128-134. https://doi.org/10.1097/MPG.0000000000001699

Lien, E. L., Richard, C., \& Hoffman, D. R. (2017). DHA and ARA addition to infant formula: current status and future research directions. Prostaglandins Leukotrienes and Essential Fatty Acids. https://doi.org/10.1016/j.plefa.2017.09.005

Lin, J. (2004). Too much short chain fatty acids cause neonatal necrotizing enterocolitis. Medical Hypotheses, 62(2), 291-293. https://doi.org/10.1016/S0306-9877(03)00333-5

Linderborg, K. M., Kalpio, M., Mäkelä, J., Niinikoski, H., Kallio, H. P., \& Lagström, H. (2014). Tandem mass spectrometric analysis of human milk Triacylglycerols from normal weight and overweight mothers on different diets. Food Chemistry, 146, 583-590. https://doi.org/10.1016/j.foodchem.2013.09.092

Litmanovitz, I., Davidson, K., Eliakim, A., Regev, R. H., Dolfin, T., Arnon, S., ... Nemet, D. (2013). High Beta-palmitate formula and bone strength in term infants: a randomized, double-blind, controlled trial. Calcified Tissue International, 92(1), 35-41. https://doi.org/10.1007/s00223-012-9664-8

Liu, H., Radlowski, E. C., Conrad, M. S., Li, Y., Dilger, R. N., \& Johnson, R. W. (2014). Early supplementation of phospholipids and gangliosides affects brain and cognitive development in neonatal piglets. The Journal of Nutrition, 144(12), 1903-9. https://doi.org/10.3945/jn.114.199828

Liu, Z., Logan, A., Cocks, B. G., \& Rochfort, S. (2017). Seasonal variation of polar lipid content in bovine milk. Food Chemistry, 237, 865-869. https://doi.org/10.1016/j.foodchem.2017.06.038

Lloyd, B., Halter, R. J., Kuchan, M. J., Baggs, G. E., Ryan, A. S., \& Masor, M. L. (1999). Formula tolerance in postbreastfed and exclusively formula-fed infants. Pediatrics, 103(1), 
E7. Retrieved from http://www.ncbi.nlm.nih.gov/pubmed/9917487

López-López, A., López-Sabater, M. C., Campoy-Folgoso, C., Rivero-Urgell, M., \& CastelloteBargalló, A. I. (2002). Fatty acid and sn-2 fatty acid composition in human milk from Granada (Spain) and in infant formulas. European Journal of Clinical Nutrition, 56(12), 1242-54. https://doi.org/10.1038/sj.ejcn.1601470

Makrides, M., Neumann, M. A., Jeffrey, B., Lien, E. L., \& Gibson, R. A. (2000). A randomized trial of different ratios of linoleic to alpha-linolenic acid in the diet of term infants: effects on visual function and growth. The American Journal of Clinical Nutrition, 71(1), 120-9. Retrieved from http://ajcn.nutrition.org/content/71/1/120.full.pdf + html

Manson, W. G., \& Weaver, L. T. (1997). Fat digestion in the neonate, (fig 2), 206-211.

Månsson, H. L. (2008). Fatty acids in bovine milk fat. Food \& Nutrition Research, 52, 1-3. https://doi.org/10.3402/fnr.v52i0.1821

Marangoni, F., Agostoni, C., Lammardo, A. M., Bonvissuto, M., Giovannini, M., Galli, C., \& Riva, E. (2002). Polyunsaturated fatty acids in maternal plasma and in breast milk. Prostaglandins Leukot.Essent.Fatty Acids, 66(0952-3278), 535-540. https://doi.org/10.1054/plef.396

Marangoni, F., Agostoni, C., Lammardo, a M., Giovannini, M., Galli, C., \& Riva, E. (2000). Polyunsaturated fatty acid concentrations in human hindmilk are stable throughout 12months of lactation and provide a sustained intake to the infant during exclusive breastfeeding: an Italian study. Br J Nutr., 84(1), 103-109. https://doi.org/10.1017/S0007114500001288

Marten, B., Pfeuffer, M., \& Schrezenmeir, J. (2006). Medium-chain triglycerides. International Dairy Journal, 16(11), 1374-1382. https://doi.org/10.1016/j.idairyj.2006.06.015

Martini, M., Salari, F., \& Altomonte, I. (2016). The Macrostructure of Milk Lipids: The Fat Globules. Critical Reviews in Food Science and Nutrition, 56(7), 1209-1221. https://doi.org/10.1080/10408398.2012.758626

Massiera, F., Barbry, P., Guesnet, P., Joly, A., Luquet, S., Moreilhon-Brest, C., ... Ailhaud, G. 
(2010). A Western-like fat diet is sufficient to induce a gradual enhancement in fat mass over generations. Journal of Lipid Research, 51(8), 2352-61.

https://doi.org/10.1194/jlr.M006866

Mathiassen, J. H., Nejrup, R. G., Frøkiaer, H., Nilsson, Å., Ohlsson, L., \& Hellgren, L. I. (2015). Emulsifying triglycerides with dairy phospholipids instead of soy lecithin modulates gut lipase activity. European Journal of Lipid Science and Technology, 117(10), 1522-1539. https://doi.org/10.1002/ejlt.201400505

Mendonça, M. A., Araújo, W. M. C., Borgo, L. A., \& Alencar, E. de R. (2017). Lipid profile of different infant formulas for infants. PloS One, 12(6), e0177812. https://doi.org/10.1371/journal.pone.0177812

Michalski, M.-C. (2009). Specific molecular and colloidal structures of milk fat affecting lipolysis, absorption and postprandial lipemia. European Journal of Lipid Science and Technology, 111(5), 413-431. https://doi.org/10.1002/ejlt.200800254

Møller, H. K., Thymann, T., Fink, L. N., Frokiaer, H., Kvistgaard, A. S., \& Sangild, P. T. (2011). Bovine colostrum is superior to enriched formulas in stimulating intestinal function and necrotising enterocolitis resistance in preterm pigs. The British Journal of Nutrition, 105(1), 44-53. https://doi.org/10.1017/S0007114510003168

Moltó-Puigmartí, C., Castellote, A. I., Carbonell-Estrany, X., \& López-Sabater, M. C. (2011). Differences in fat content and fatty acid proportions among colostrum, transitional, and mature milk from women delivering very preterm, preterm, and term infants. Clinical Nutrition, 30(1), 116-123. https://doi.org/10.1016/j.clnu.2010.07.013

Morera Pons, S., Castellote Bargalló, A. I., \& López Sabater, M. C. (1998). Analysis of human milk triacylglycerols by high-performance liquid chromatography with light-scattering detection. Journal of Chromatography A, 823(1-2), 475-482. https://doi.org/10.1016/S0021-9673(98)00584-6

Mudd, A. T., Alexander, L. S., Berding, K., Waworuntu, R. V., Berg, B. M., Donovan, S. M., \& Dilger, R. N. (2016). Dietary Prebiotics, Milk Fat Globule Membrane, and Lactoferrin 
Affects Structural Neurodevelopment in the Young Piglet. Frontiers in Pediatrics, 4. https://doi.org/10.3389/fped.2016.00004

Mueller, N. T., Bakacs, E., Combellick, J., Grigoryan, Z., \& Dominguez-Bello, M. G. (2015). The infant microbiome development: mom matters. Trends in Molecular Medicine, 21(2), 109-17. https://doi.org/10.1016/j.molmed.2014.12.002

Nafday, S. M., Chen, W., Peng, L., Babyatsky, M. W., Holzman, I. R., \& Lin, J. (2005). Shortchain fatty acids induce colonic mucosal injury in rats with various postnatal ages. Pediatric Research, 57(2), 201-204. https://doi.org/10.1203/01.PDR.0000150721.83224.89

Nayak, U., Kanungo, S., Zhang, D., Ross Colgate, E., Carmolli, M. P., Dey, A., ... Mychaleckyj, J. C. (2017). Influence of maternal and socioeconomic factors on breast milk fatty acid composition in urban, low-income families. Maternal \& Child Nutrition, 13(4), e12423. https://doi.org/10.1111/men.12423

Nilsson, Å. (2016). Role of Sphingolipids in Infant Gut Health and Immunity. The Journal of Pediatrics, 173, S53-S59. https://doi.org/10.1016/j.jpeds.2016.02.076

Norris, G. H., Jiang, C., Ryan, J., Porter, C. M., \& Blesso, C. N. (2016). Milk sphingomyelin improves lipid metabolism and alters gut microbiota in high fat diet-fed mice. Journal of Nutritional Biochemistry, 30, 93-101. https://doi.org/10.1016/j.jnutbio.2015.12.003

Norris, G. H., Porter, C. M., Jiang, C., Millar, C. L., \& Blesso, C. N. (2017). Dietary sphingomyelin attenuates hepatic steatosis and adipose tissue inflammation in high-fatdiet-induced obese mice. Journal of Nutritional Biochemistry, 40, 36-43. https://doi.org/10.1016/j.jnutbio.2016.09.017

Nowacki, J., Lee, H.-C., Lien, R., Cheng, S.-W., Li, S.-T., Yao, M., ... Mutungi, G. (2014a). Stool fatty acid soaps, stool consistency and gastrointestinal tolerance in term infants fed infant formulas containing high sn-2 palmitate with or without oligofructose: a doubleblind, randomized clinical trial. Nutrition Journal, 13, 105. https://doi.org/10.1186/14752891-13-105 
Nowacki, J., Lee, H.-C., Lien, R., Cheng, S.-W., Li, S.-T., Yao, M., ... Mutungi, G. (2014b). Stool fatty acid soaps, stool consistency and gastrointestinal tolerance in term infants fed infant formulas containing high sn-2 palmitate with or without oligofructose: a doubleblind, randomized clinical trial. Nutrition Journal, 13, 105. https://doi.org/10.1186/14752891-13-105

Ogawa, A., Nosaka, N., Kasai, M., Aoyama, T., Okazaki, M., Igarashi, O., \& Kondo, K. (2007). Dietary medium- and long chain triacylglycerols accelerate diet induced thermogenesis in humans. Journal of Oleo Science, 56(6), 283-7.

Oliveira De Souza, C., Efigênia, M., Leite, Q., Lasekan, J., Baggs, G., Pinho, L. S., ... CostaRibeiro, H. (2017). Milk protein-based formulas containing different oils affect fatty acids balance in term infants: A randomized blinded crossover clinical trial. Lipids in Health and Disease, 16. https://doi.org/10.1186/s12944-017-0457-y

Oosting, A., Kegler, D., van de Heijning, B. J. M., Verkade, H. J., \& van der Beek, E. M. (2015). Reduced linoleic acid intake in early postnatal life improves metabolic outcomes in adult rodents following a Western-style diet challenge. Nutrition Research, 35(9), 800811. https://doi.org/10.1016/j.nutres.2015.06.010

Oosting, A., Kegler, D., Wopereis, H. J., Teller, I. C., van de Heijning, B. J. M., Verkade, H. J., \& van der Beek, E. M. (2012). Size and phospholipid coating of lipid droplets in the diet of young mice modify body fat accumulation in adulthood. Pediatric Research, 72(4), 362-369. https://doi.org/10.1038/pr.2012.101

Oshida, K., Shimizu, T., Takase, M., Tamura, Y., Shimizu, T., \& Yamashiro, Y. (2003). Effects of Dietary Sphingomyelin on Central Nervous System Myelination in Developing Rats. Pediatric Research, 53(4), 589-593. https://doi.org/10.1203/01.PDR.0000054654.73826.AC

Pan, X. L., \& Izumi, T. (2000). Variation of the ganglioside compositions of human milk, cow's milk and infant formulas. Early Human Development, 57(1), 25-31. https://doi.org/10.1016/S0378-3782(99)00051-1 
Peng, L., He, Z., Chen, W., Holzman, I. R., \& Lin, J. (2007). Effects of butyrate on intestinal barrier function in a caco-2 cell monolayer model of intestinal barrier. Pediatric Research, 61(1), 37-41. https://doi.org/10.1203/01.pdr.0000250014.92242.f3

Poppitt, S. D., McGregor, R. A., Wiessing, K. R., Goyal, V. K., Chitkara, A. J., Gupta, S., ... McConnell, M. A. (2014). Bovine Complex Milk Lipid Containing Gangliosides for Prevention of Rotavirus Infection and Diarrhoea in Northern Indian Infants. Journal of Pediatric Gastroenterology and Nutrition, 59(2), 167-171.

https://doi.org/10.1097/MPG.0000000000000398

Prosser, C. G., Svetashev, V. I., Vyssotski, M. V., \& Lowry, D. J. (2010). Composition and distribution of fatty acids in triglycerides from goat infant formulas with milk fat. Journal of Dairy Science, 93(7), 2857-2862. https://doi.org/10.3168/jds.2009-2946

Qi, C., Sun, J., Xia, Y., Yu, R., Wei, W., Xiang, J., ... Wang, X. (2018). Fatty Acid Profile and the sn-2 Position Distribution in Triacylglycerols of Breast Milk during Different Lactation Stages. Journal of Agricultural and Food Chemistry, 66(12), 3118-3126. https://doi.org/10.1021/acs.jafc.8b01085

Quinlan, P. T., Lockton, S., Irwin, J., \& Lucas, A. L. (1995). The relationship between stool hardness and stool composition in breast- and formula-fed infants. Journal of Pediatric Gastroenterology and Nutrition, 20(1), 81-90. Retrieved from http://www.ncbi.nlm.nih.gov/pubmed/7884622

Rioux, F. M., \& Innis, S. M. (1993). Cholesterol and fatty acid metabolism in piglets fed sow milk or infant formula with or without addition of cholesterol. Metabolism: Clinical and Experimental, 42(12), 1552-9. Retrieved from http://www.ncbi.nlm.nih.gov/pubmed/8246769

Rist, L., Mueller, A., Barthel, C., Snijders, B., Jansen, M., Simões-Wüst, a P., ... Thijs, C. (2007). Influence of organic diet on the amount of conjugated linoleic acids in breast milk of lactating women in the Netherlands. The British Journal of Nutrition, 97(4), 735-743. https://doi.org/10.1017/S0007114507433074 
RIVM. (2016). NEVO-online versie 2016/5.0, RIVM, Bilthoven, 2016.

Rueda, R. (2007). The role of dietary gangliosides on immunity and the prevention of infection. British Journal of Nutrition, 98(S1), S68-73. https://doi.org/10.1017/S0007114507832946

Rueda, R., Sabatel, J. L., Maldonado, J., Molina-Font, J. A., \& Gil, A. (1998). Addition of gangliosides to an adapted milk formula modifies levels of fecal Escherichia coli in preterm newborn infants. The Journal of Pediatrics, 133(1), 90-4. Retrieved from http://www.ncbi.nlm.nih.gov/pubmed/9672517

Sala-Vila, A., Castellote, A. I., Rodriguez-Palmero, M., Campoy, C., \& López-Sabater, M. C. (2005). Lipid composition in human breast milk from Granada (Spain): Changes during lactation. Nutrition, 21(4), 467-473. https://doi.org/10.1016/j.nut.2004.08.020

Scalfi, L., Coltorti, a., \& Contaldo, F. (1991). Postprandial thermogenesis in lean and obese subjects after meals supplemented with medium-chain and long-chain triglycerides. American Journal of Clinical Nutrition, 53(5), 1130-1133.

Schipper, L., Oosting, A., Scheurink, A. J. W., van Dijk, G., \& van der Beek, E. M. (2016). Reducing dietary intake of linoleic acid of mouse dams during lactation increases offspring brain n-3 LCPUFA content. Prostaglandins, Leukotrienes and Essential Fatty Acids (PLEFA), 110, 8-15. https://doi.org/10.1016/j.plefa.2016.05.001

Schipper, L., van Dijk, G., Broersen, L. M., Loos, M., Bartke, N., Scheurink, A. J., \& van der Beek, E. M. (2016). A Postnatal Diet Containing Phospholipids, Processed to Yield Large, Phospholipid-Coated Lipid Droplets, Affects Specific Cognitive Behaviors in Healthy Male Mice. Journal of Nutrition, 146(6), 1155-1161. https://doi.org/10.3945/jn.115.224998

Schnabl, K. L., Larsen, B., Van Aerde, J. E., Lees, G., Evans, M., Belosevic, M., .. Clandinin, M. T. (2009). Gangliosides Protect Bowel in an Infant Model of Necrotizing Enterocolitis by Suppressing Proinflammatory Signals. Journal of Pediatric Gastroenterology and Nutrition, 49(4), 382-392. https://doi.org/10.1097/MPG.0b013e3181b6456d

Scholtens, S., Wijga, A. H., Smit, H. a, Brunekreef, B., de Jongste, J. C., Gerritsen, J., \& 
Seidell, J. C. (2009). Long-chain polyunsaturated fatty acids in breast milk and early weight gain in breast-fed infants. The British Journal of Nutrition, 101(1), 116-121. https://doi.org/10.1017/S0007114508993521

Scholtz, S. A., Gottipati, B. S., Gajewski, B. J., \& Carlson, S. E. (2013). Dietary Sialic Acid and Cholesterol Influence Cortical Composition in Developing Rats. Journal of Nutrition, 143(2), 132-135. https://doi.org/10.3945/jn.112.169508

Shamir, R., Nganga, A., Berkowitz, D., Diamond, E., Lischinsky, S., Lombardo, D., \& Shehadeh, N. (2003). Serum levels of bile salt-stimulated lipase and breast feeding. Journal of Pediatric Endocrinology \& Metabolism : JPEM, 16(9), 1289-94. Retrieved from http://www.ncbi.nlm.nih.gov/pubmed/14714753

Shi, Y.-D., Sun, G.-Q., Zhang, Z.-G., Deng, X., Kang, X.-H., Liu, Z.-D., ... Sheng, Q.-H. (2011). The chemical composition of human milk from Inner Mongolia of China. Food Chemistry, 127(3), 1193-8. https://doi.org/10.1016/j.foodchem.2011.01.123

Simopoulos, A. P., Koletzko, B., Anderson, R. E., Hornstra, G., Mensink, R. P., Weksler, B. B., ... Sprecher, H. (1994). The 1st Congress of the International Society for the Study of Fatty Acids and Lipids (ISSFAL): fatty acids and lipids from cell biology to human disease. Journal of Lipid Research, 35(1), 169-73. Retrieved from http://www.ncbi.nlm.nih.gov/pubmed/7908025

Skrivanova, E., Skrivanova, V., Volek, Z., \& Marounek, M. (2009). Effect of triacylglycerols of medium-chain fatty acids on growth rate and mortality of rabbits weaned at 25 and 35 days of age. Veterinarni Medicina, 54(1), 19-24.

Smet, E. De, Mensink, R. P., \& Plat, J. (2012). Effects of plant sterols and stanols on intestinal cholesterol metabolism: Suggested mechanisms from past to present. Molecular Nutrition \& Food Research, 56(7), 1058-1072. https://doi.org/10.1002/mnfr.201100722

Stokes, C. R. (2017). The development and role of microbial-host interactions in gut mucosal immune development. Journal of Animal Science and Biotechnology, 8(1), 12. https://doi.org/10.1186/s40104-016-0138-0 
Stoop, W. M., Bovenhuis, H., Heck, J. M. L., \& van Arendonk, J. A. M. (2009). Effect of lactation stage and energy status on milk fat composition of Holstein-Friesian cows. Journal of Dairy Science, 92(4), 1469-1478. https://doi.org/10.3168/jds.2008-1468

Straarup, E. M., Lauritzen, L., Faerk, J., Høy Deceased, C.-E., Michaelsen, K. F., Deceased, C. H. L., \& Michaelsen, K. F. (2006). The stereospecific triacylglycerol structures and Fatty Acid profiles of human milk and infant formulas. Journal of Pediatric Gastroenterology and Nutrition, 42(3), 293-9. https://doi.org/10.1097/01.mpg.0000214155.51036.4f

Sun, C., Wei, W., Su, H., Zou, X., \& Wang, X. (2018). Evaluation of sn -2 fatty acid composition in commercial infant formulas on the Chinese market: A comparative study based on fat source and stage. Food Chemistry, 242, 29-36.

https://doi.org/10.1016/j.foodchem.2017.09.005

Sun, C., Zou, X., Yao, Y., Jin, J., Xia, Y., Huang, J., ... Wang, X. (2016). Evaluation of fatty acid composition in commercial infant formulas on the Chinese market: A comparative study based on fat source and stage. International Dairy Journal, 42-51.

Tanaka, K., Hosozawa, M., Kudo, N., Yoshikawa, N., Hisata, K., Shoji, H., ... Shimizu, T. (2013). The pilot study: Sphingomyelin-fortified milk has a positive association with the neurobehavioural development of very low birth weight infants during infancy, randomized control trial. Brain and Development, 35(1), 45-52. https://doi.org/10.1016/j.braindev.2012.03.004

Telliez, F., Bach, V., Dewasmes, G., Leke, A., \& Libert, J. (1998). Effects of medium- and long-chain triglycerides on sleep and thermoregulatory processes in neonates. Journal of Sleep Research, 7, 31-39.

Telliez, F., Bach, V., Leke, A., Chardon, K., \& Libert, J. (2002). Feeding behavior in neonates whose diet contained medium-chain triacylglycerols: short-term effects on thermoregulation and sleep. The American Journal of Clinical Nutrition, 76(5), 10911095.

Timby, N., Domellof, E., Hernell, O., Lonnerdal, B., \& Domellof, M. (2014). 
Neurodevelopment, nutrition, and growth until 12 mo of age in infants fed a low-energy, low-protein formula supplemented with bovine milk fat globule membranes: a randomized controlled trial. American Journal of Clinical Nutrition, 99(4), 860-868. https://doi.org/10.3945/ajen.113.064295

Timby, N., Hernell, O., Vaarala, O., Melin, M., Lönnerdal, B., \& Domellöf, M. (2015). Infections in infants fed formula supplemented with bovine milk fat globule membranes. Journal of Pediatric Gastroenterology and Nutrition, 60(3), 384-9. https://doi.org/10.1097/MPG.0000000000000624

Timby, N., Lönnerdal, B., Hernell, O., \& Domellöf, M. (2014). Cardiovascular risk markers until 12 mo of age in infants fed a formula supplemented with bovine milk fat globule membranes. Pediatric Research, 76(4), 394-400. https://doi.org/10.1038/pr.2014.110

Tu, A., Ma, Q., Bai, H., \& Du, Z. (2017). A comparative study of triacylglycerol composition in Chinese human milk within different lactation stages and imported infant formula by SFC coupled with Q-TOF-MS. Food Chemistry, 221, 555-567. Retrieved from http://www.sciencedirect.com/science/article/pii/S0308814616319884

Van de Heijning, B. J. M., Oosting, A., Kegler, D., \& Van der Beek, E. M. (2017). An increased dietary supply of medium-chain fatty acids during early weaning in rodents prevents excessive fat accumulation in adulthood. Nutrients, $9(6)$. https://doi.org/10.3390/nu9060631

van Nieuwenhuyzen, W., \& Tomás, M. C. (2008). Update on vegetable lecithin and phospholipid technologies. European Journal of Lipid Science and Technology, 110(5), 472-486. https://doi.org/10.1002/ejlt.200800041

van Valenberg, H. J. F., Hettinga, K. A., Dijkstra, J., Bovenhuis, H., \& Feskens, E. J. M. (2013). Concentrations of n-3 and n- 6 fatty acids in Dutch bovine milk fat and their contribution to human dietary intake. Journal of Dairy Science, 96(7), 4173-81. Retrieved from http://www.ncbi.nlm.nih.gov/pubmed/23664339

Verardo, V., Gómez-caravaca, A. M., Arráez-román, D., \& Hettinga, K. (2017). Recent 
Advances in Phospholipids from Colostrum, Milk and Dairy By-Products. International Journal of Molecular Sciences, 18(1), 1-23. https://doi.org/10.3390/ijms18010173

Wan, Z.-X., Wang, X.-L., Xu, L., Geng, Q., \& Zhang, Y. (2010). Lipid content and fatty acids composition of mature human milk in rural North China. The British Journal of Nutrition, 103(6), 913-916. https://doi.org/10.1017/S0007114509992455

Wang, B., Brand-Miller, J., McVeagh, P., \& Petocz, P. (2001). Concentration and distribution of sialic acid in human milk and infant formulas. The American Journal of Clinical Nutrition, 74(4), 510-5. Retrieved from http://www.ncbi.nlm.nih.gov/pubmed/11566650

Wang, M., Monaco, M. H., \& Donovan, S. M. (2016). Impact of early gut microbiota on immune and metabolic development and function. Seminars in Fetal and Neonatal Medicine, 21(6), 380-387. https://doi.org/10.1016/j.siny.2016.04.004

Wang, Y.-H., Mai, Q.-Y., Qin, X.-L., Yang, B., Wang, Z.-L., \& Chen, H.-T. (2010). Establishment of an Evaluation Model for Human Milk Fat Substitutes. Journal of Agricultural and Food Chemistry, 58(1), 642-649. https://doi.org/10.1021/jf903048p

Weber, M., Grote, V., Closa-Monasterolo, R., Escribano, J., Langhendries, J.-P., Dain, E., ... European Childhood Obesity Trial Study Group. (2014). Lower protein content in infant formula reduces BMI and obesity risk at school age: follow-up of a randomized trial. The American Journal of Clinical Nutrition, 99(5), 1041-1051.

https://doi.org/10.3945/ajcn.113.064071

Wijga, A., Houwelingen, A. C., Smit, H. A., Kerkhof, M., Vos, A. P., Neijens, H. J., ... Study, P. B. C. (2003). Fatty acids in breast milk of allergic and non-allergic mothers: The PIAMA birth cohort study. Pediatric Allergy and Immunology, 14(3), 156-162.

Wu, T.-C., Lau, B.-H., Chen, P.-H., Wu, L.-T., \& Tang, R.-B. (2010). Fatty acid composition of Taiwanese human milk. Journal of the Chinese Medical Association : JCMA, 73(11), 5818. https://doi.org/10.1016/S1726-4901(10)70127-1

Yao, M., Lien, E. L., Capeding, M. R. Z., Fitzgerald, M., Ramanujam, K., Yuhas, R., ... DeRusso, P. A. (2014a). Effects of term infant formulas containing high sn-2 palmitate 
with and without oligofructose on stool composition, stool characteristics, and bifidogenicity. Journal of Pediatric Gastroenterology and Nutrition, 59(4), 440-8. https://doi.org/10.1097/MPG.0000000000000443

Yao, M., Lien, E. L., Capeding, M. R. Z., Fitzgerald, M., Ramanujam, K., Yuhas, R., ... DeRusso, P. A. (2014b). Effects of term infant formulas containing high sn-2 palmitate with and without oligofructose on stool composition, stool characteristics, and bifidogenicity. Journal of Pediatric Gastroenterology and Nutrition, 59(4), 440-8. https://doi.org/10.1097/MPG.0000000000000443

Yaron, S., Shachar, D., Abramas, L., Riskin, A., Bader, D., Litmanovitz, I., ... Shaoul, R. (2013). Effect of high $\beta$-palmitate content in infant formula on the intestinal microbiota of term infants. Journal of Pediatric Gastroenterology and Nutrition, 56(4), 376-81. Retrieved from http://www.ncbi.nlm.nih.gov/pubmed/23201699

Yuhas, R., Pramuk, K., \& Lien, E. L. (2006). Human milk fatty acid composition from nine countries varies most in DHA. Lipids, 41(9), 851-8. Retrieved from http://www.ncbi.nlm.nih.gov/pubmed/17152922

Zavaleta, N., Kvistgaard, A. S., Graverholt, G., Respicio, G., Guija, H., Valencia, N., \& Lönnerdal, B. (2011). Efficacy of an MFGM-enriched complementary food in diarrhea, anemia, and micronutrient status in infants. Journal of Pediatric Gastroenterology and Nutrition, 53(5), 561-8. https://doi.org/10.1097/MPG.0b013e318225cdaf

Zeisel, S. H., Char, D., \& Sheard, N. F. (1986). Choline, phosphatidylcholine and sphingomyelin in human and bovine milk and infant formulas. The Journal of Nutrition, 116(1), 50-8. Retrieved from http://www.ncbi.nlm.nih.gov/pubmed/3944656

Zhang, L., van Dijk, A. D. J., \& Hettinga, K. (2016). An interactomics overview of the human and bovine milk proteome over lactation. Proteome Science, 15, 1. https://doi.org/10.1186/s12953-016-0110-0

Zou, L., Pande, G., \& Akoh, C. C. (2016). Infant Formula Fat Analogs and Human Milk Fat: New Focus on Infant Developmental Needs. Annual Review of Food Science and 
Technology, 7(1), 139-165. https://doi.org/10.1146/annurev-food-041715-033120

Zou, X., Guo, Z., Jin, Q., Huang, J., Cheong, L., Xu, X., \& Wang, X. (2015). Composition and microstructure of colostrum and mature bovine milk fat globule membrane. Food Chemistry, 185, 362-70. https://doi.org/10.1016/j.foodchem.2015.03.145

Zou, X., Huang, J., Jin, Q., Guo, Z., Liu, Y., Cheong, L., ... Wang, X. (2013). Lipid composition analysis of milk fats from different mammalian species: potential for use as human milk fat substitutes. J Agric Food Chem., 61(29), 7070-7080. https://doi.org/10.1021/jf401452y

\section{Abbreviation list}

ALA alpha-linolenic acid

ARA arachidonic acid

DHA docosahexaenoic acid

IF Infant formula

LA linoleic acid

LCFA long-chain fatty acids $(>\mathrm{C} 11: 0)$

LCSFA long-chain saturated fatty acids

MAG mono-acylglycerol

MCFA medium-chain fatty acids (C6:0-C10)

MFGM Milk fat globular membrane

MFG Milk fat globules

MUFA mono-unsaturated fatty acids

PUFA poly-unsaturated fatty acids

SCFA short-chain fatty acids $(<\mathrm{C} 6: 0)$

sn $\quad$ stereospecific nomenclature

TAG triacylglycerol 
Table 1: Fatty acid composition (g/100 g fatty acids) of human milk, bovine milk and infant formulas (IF) containing different fat sources

(mean+range).

\begin{tabular}{|c|c|c|c|c|c|c|c|c|}
\hline & & & \multicolumn{3}{|c|}{ Milk } & \multicolumn{3}{|c|}{ IF } \\
\hline \multicolumn{3}{|c|}{ Fatty acid } & $\begin{array}{l}\text { Human milk - } \\
\text { Europe }^{1, \text { a }}\end{array}$ & $\begin{array}{l}\text { Human milk - } \\
\text { Asia }^{2, \text { a }}\end{array}$ & Bovine milk ${ }^{3}$ & $\begin{array}{c}\text { IFs containing } \\
\text { vegetable fat blends } \\
4, \mathrm{~b}\end{array}$ & $\begin{array}{l}\text { IFs containing milk } \\
\text { fat }{ }^{5, \mathrm{c}}\end{array}$ & $\begin{array}{l}\text { IFs containing palm } \\
\text { oil free vegetable fat } \\
\text { blend } 6, \mathrm{~d}\end{array}$ \\
\hline SCFA & C4:0 & Butyric acid & ND & ND & $3.50(3.07-3.78)$ & $\mathrm{ND}$ & 2.4 & $\mathrm{ND}$ \\
\hline \multirow{3}{*}{ MCFA } & C6:0 & Caproic acid & $0.39^{8}$ & $0.07^{7}$ & $2.29(2.07-2.46)$ & $\mathrm{ND}$ & 1.3 & 0.2 \\
\hline & C8:0 & Caprylic acid & $0.19(0.09-0.24)$ & $0.17(0.11-0.28)$ & $1.38(1.26-1.51)$ & $1.2(0.4-2.1)$ & 1.7 & 2.5 \\
\hline & C10:0 & Capric acid & $1.29(0.83-1.63)$ & $1.31(0.52-2.48)$ & $2.94(2.60-3.23)$ & $1.1(0.1-1.7)$ & 2.2 & 1.8 \\
\hline \multirow{11}{*}{ LCFA } & C12:0 & Lauric acid & $5.98(4.15-8.33)$ & $5.56(2.97-13.82)$ & $3.87(3.50-4.28)$ & $5.4(0.2-13.6)$ & 6.3 & 13.4 \\
\hline & C14:0 & Myristic acid & $6.44(4.98-9.38)$ & $5.70(3.50-12.12)$ & $11.29(10.67-11.94)$ & $4.6(0.9-7.0)$ & 7.2 & 5.2 \\
\hline & C14:1 & Myristoleic acid & $0.18^{8}$ & $0.26(0.03-1.11)^{9}$ & $1.08(1.01-1.19)$ & ND & 0.8 & $\mathrm{ND}$ \\
\hline & C15:0 & Pentadecanoic acid & $0.25(0.16-0.32)$ & $0.20(0.08-0.50)$ & $1.03(0.97-1.10)$ & $\mathrm{ND}$ & 0.6 & $\mathrm{ND}$ \\
\hline & C16:0 & Palmitic acid & $21.93(15.43-25.62)$ & $21.78(17.55-29.00)$ & $30.20(28.31-31.85)$ & $26.3(15.9-31.7)$ & 18.9 & 7.7 \\
\hline & C16:1 n-7 & Palmitoleic acid & $1.98(1.65-2.31)$ & $2.44(1.29-4.59)$ & $1.57(1.45-1.68)$ & $0.6(0.2-1.1)$ & 1.1 & 0.1 \\
\hline & C17:0 & $\begin{array}{l}\text { Heptadecanoic } \\
\text { acid }\end{array}$ & $0.29(0.22-0.33)$ & $0.28(0.19-0.41)$ & $0.59(0.53-0.72)$ & ND & 0.3 & ND \\
\hline & C18:0 & Stearic acid & $7.37(5.58-9.52)$ & $5.58(3.90-6.79)$ & $9.85(8.75-11.39)$ & $5.3(3.2-7.7)$ & 6.7 & 3.2 \\
\hline & C18:1 n-9 & Oleic acid & $36.30(28.93-41.69)$ & $30.80(21.85-36.96)$ & $21.62(19.37-24.25)$ & $37.6(31.6-42.3)$ & 28.1 & 43.3 \\
\hline & C18:2n-6 & Linoleic acid (LA) & $13.99(10.16-16.59)$ & $16.90(7.53-24.29)$ & $1.44(1.36-1.76)$ & $14.0(10.0-18.9)$ & 16.7 & 20.5 \\
\hline & C18:3 n-3 & $\begin{array}{l}\text { Alpha-linolenic } \\
\text { acid (ALA) }\end{array}$ & $0.76(0.49-1.05)$ & $1.47(0.35-4.06)$ & $0.49(0.45-0.57)$ & $1.6(1.2-2.0)$ & 1.5 & 1.8 \\
\hline
\end{tabular}




\begin{tabular}{|c|c|c|c|c|c|c|c|}
\hline C20:0 & Arachidic acid & $0.21(0.14-0.31)$ & $0.32(0.03-2.97)$ & $0.14(0.12-0.17)$ & ND & 0.3 & 0.3 \\
\hline$C 20: 3 n-6$ & $\begin{array}{l}\text { Dihomo-gamma- } \\
\text { linolenic acid } \\
\text { (DGLA) }\end{array}$ & $0.38(0.29-0.52)$ & $0.42(0.23-0.83)$ & $0.07(0.06-0.08)$ & ND & ND & ND \\
\hline $\mathrm{C} 20: 5 \mathrm{n}-3$ & $\begin{array}{l}\text { Eicosapentaenoic } \\
\text { acid (EPA) }\end{array}$ & $0.09(0.05-0.13)$ & $0.31(0.07-1.59)$ & 0.07 (0.06-0.09) & ND & - & 0.0 \\
\hline C22:0 & Behenic acid & $0.09(0.05-0.13)$ & $0.08(0.05-0.14)$ & $0.06(0.05-0.07)$ & ND & 0.1 & 0.4 \\
\hline C20:4 n-6 & $\begin{array}{l}\text { Arachidonic acid } \\
\text { (ARA) }\end{array}$ & $0.47(0.37-0.64)$ & $0.64(0.30-2.57)$ & $0.04(0.03-0.05)$ & $0.3(0.1-0.4)$ & - & 0.3 \\
\hline C24:0 & Tetracosanoic acid & $0.07(0.03-0.16)$ & $0.07(0.01-0.14)$ & $0.05(0.04-0.07)$ & ND & ND & 0.1 \\
\hline C22:6 n-3 & $\begin{array}{l}\text { Docosahexaenoic } \\
\text { acid (DHA) }\end{array}$ & $0.28(0.18-0.42)$ & $0.55(0.19-1.13)$ & $0.01(0.00-0.04)$ & 0.2 & - & 0.2 \\
\hline Total SC/MCFA & & 1.86 & 2.14 & 10.11 & 2.3 & 7.6 & 4.5 \\
\hline Total LCSFA & & 42.62 & 39.59 & 57.08 & 41.6 & 40.4 & 30.3 \\
\hline Total SFA & & 44.48 & 41.73 & 67.19 & 43.9 & 48 & 34.8 \\
\hline Total MUFA & & 38.45 & 33.50 & 24.27 & 38.2 & 30.0 & 43.4 \\
\hline Total PUFA & & 15.97 & 20.27 & 2.12 & 16.1 & 18.2 & 22.8 \\
\hline Total UFA & & 54.42 & 53.77 & 26.39 & 54.3 & 48.2 & 66.2 \\
\hline
\end{tabular}

I: (Barreiro, Regal, López-Racamonde, Cepeda, \& Fente, 2017; López-López et al., 2002; Marangoni et al., 2000, 2002; MoltóPuigmartí et al., 2011; Rist et al., 2007; Sala-Vila, Castellote, Rodriguez-Palmero, Campoy, \& López-Sabater, 2005; Scholtens et al., 2009; Wijga et al., 2003), 2: (Cruz-Hernandez, Goeuriot, Giuffrida, Thakkar, \& Destaillats, 2013; Daud, Mohd-Esa, Azlan, \& Chan, 2013; Glew et al., 2001; Jiang et al., 2016; Nayak et al., 2017; Shi et al., 2011; Sun et al., 2016; Wan et al., 2010; Y.-H. Wang et al., 2010; Wu, Lau, Chen, Wu, \& Tang, 2010; Yuhas, Pramuk, \& Lien, 2006), ${ }^{3:}$ (RIVM, 2016; van Valenberg, Hettinga, Dijkstra,

Bovenhuis, \& Feskens, 2013), ${ }^{4:}$ (Straarup et al., 2006), ${ }^{5:}$ (Berger et al., 2000; Prosser, Svetashev, Vyssotski, \& Lowry, 2010), 6: (Leite et al., 2013; Lloyd et al., 1999; Oliveira De Souza et al., 2017), 7: (Wan et al., 2010), ${ }^{8:}$ (Barreiro et al., 2017), 9: (Jiang et al., 2016; Sun et al., 2016), ${ }^{a}$ studies from 2000-2018 are included, data about breast milk for infants $<12$ months of age, ${ }^{b}$ IF contained palm oils, rapeseed oil, soybean oil and coconut oil as major fats, ${ }^{c}$ IF contained bovine milk fat, corn oil, and other non specified vegetable fats, IF contained high oleic sunflower oil, coconut oil, soy oil as major fats, ND: not determined, SCFA: short-chain fatty acid, MCFA: medium-chain fatty acid, LCFA: long-chain fatty acid, LCSFA: long-chain saturated fatty acid, MUFA: mono-unsaturated fatty acid, PUFA: poly-unsaturated fatty acid, SFA: saturated fatty acids, UFA: unsaturated fatty acids, note: The analytical methods for fatty acid analyses used in the various cited papers are subject to inaccuracies in quantitative measurements over the whole range of fatty acid lengths. 
Table 2: Stereospecific distribution of C16:0 in human milk, bovine milk and vegetable fats

\begin{tabular}{ll}
\hline & $\%$ C16:0 at sn-2 \\
& position of total C16:0 \\
\hline Human milk & $70-88 \%^{1}$ \\
\hline Bovine milk & $40-45 \%^{2}$ \\
\hline Vegetable fats commonly & $10-20 \%^{3^{*}}$ \\
\hline used in IF & \\
\hline Structured triglycerides & $39-47 \%^{3^{* *}}$ \\
\hline
\end{tabular}

1: (Bracco, 1994; López-López et al., 2002; Sun et al., 2018), ${ }^{2:}$ (Bracco, 1994), ${ }^{3:(B r a c c o, ~ 1994 ; ~}$ Sun et al., 2018) * based on data of IFs containing vegetable fat without interesterified palm oil from figure 1 of Sun et al, 2018., ** based on data of IFs containing vegetable fat with interesterified palm oil from figure 1 of Sun et al, 2018 


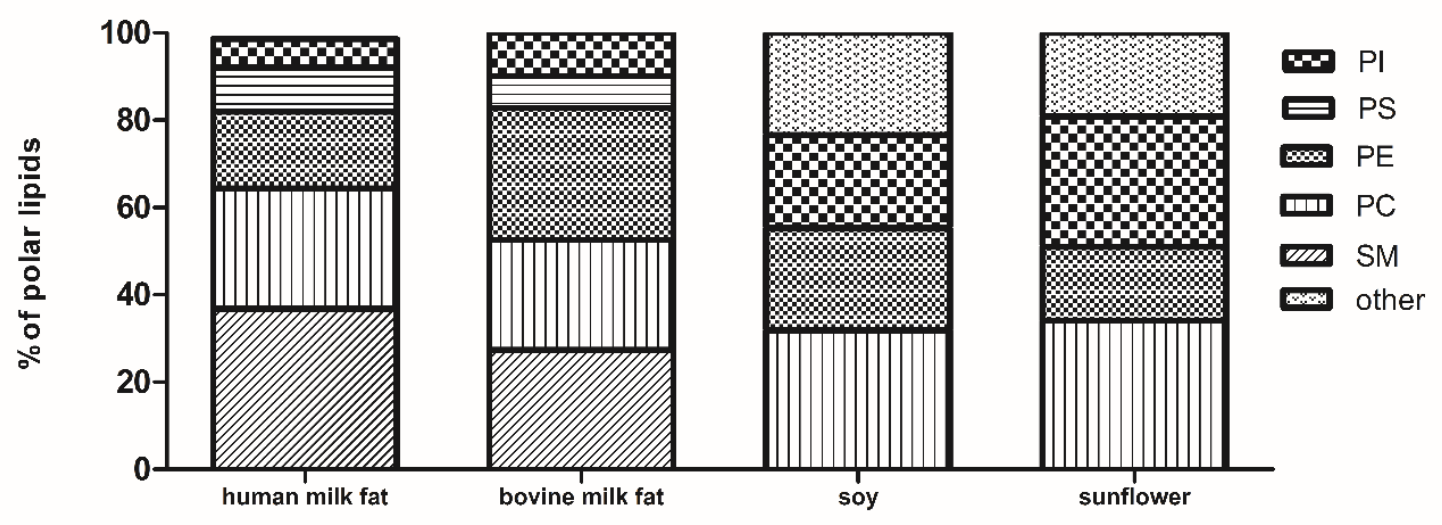

Figure 1: Relative proportion of polar lipids (\% of polar lipids) from mature human milk and bovine milk (Cilla, Diego Quintaes, Barberá, \& Alegría, 2016; X. Zou et al., 2013), and from soybeans and sunflower kernels (van Nieuwenhuyzen \& Tomás, 2008),

(PE=phosphatidylethanolamine, $P I=$ phosphatidylinositol, $P S=$ phosphatidylserine, $P C=$ phosphatidylcholine, $S M=$ sphingomyelin $)$.

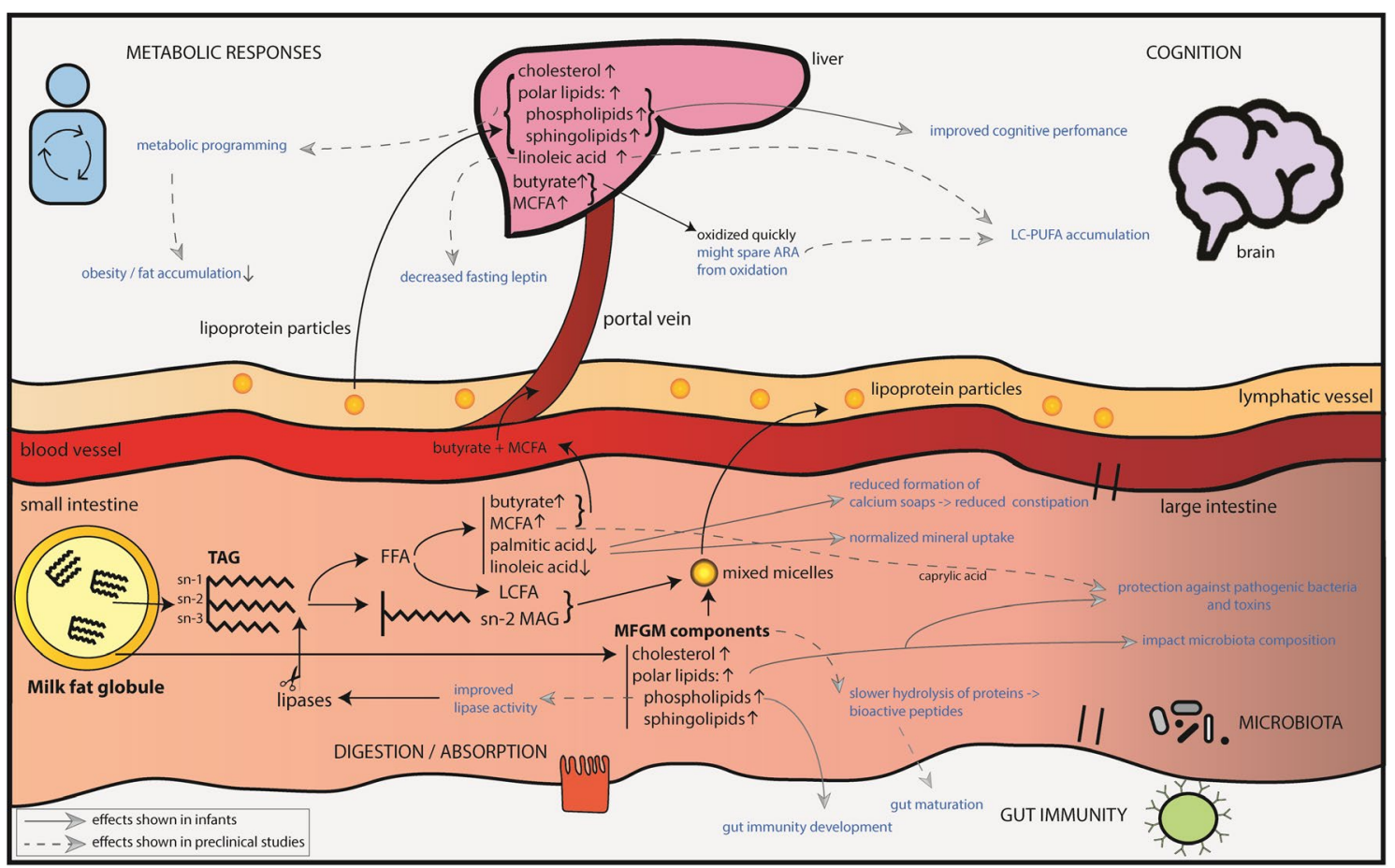

Figure 2: Schematic overview of the health effects of bovine milk fat (components) as described in this review, effects shown in infants are displayed with a solid arrow and effects shown in preclinical infants are displayed with a dotted arrow. 